\title{
Iron bioavailability from food fortification to precision nutrition. A review
}

\section{Ruth Blanco-Rojo ${ }^{a}$, M. Pilar Vaquero ${ }^{\text {b }}$ *}

a IMDEA Food Institute, CEI UAM + CSIC, Carretera de Cantoblanco 8. 28049 Madrid, Spain; ${ }^{b}$ Department of Metabolism and Nutrition, Institute of Food Science, Technology and Nutrition (ICTAN-CSIC), C/ José Antonio Novais 10, 28040 Madrid, Spain.

${ }^{*}$ Correspondence author.

E-mail address: mpvaquero@ictan.csic.es (M.P. Vaquero) 


\section{ABSTRACT}

Iron deficiency anaemia is a Worldwide Public Health problem and the fortification of food with iron is the most cost-effective prevention strategy. The correct combination of iron form and food vehicle is crucial, as well as the dietary context of consumption. Combinations of iron with an enhancer of its bioavailability and avoidance of interaction with iron inhibitors are recommended. New iron fortificants, innovative complexes, coatings and nanoparticulates, and biofortification are the main research lines. Ultimately, human assays are necessary before industrial production. In this regard, precision nutrition helps to identify the vulnerable groups that, according to genotype, dietary habits, physical activity and, most recently, metagenomic profile, may benefit from a specific iron-fortified food. This review addresses the modifiers of iron bioavailability and the main aspects to take into account in the development of iron-fortified food to prevent iron deficiency.

\section{Industrial Relevance:}

The potential target population that would benefit from iron-fortified foods is that at risk of iron deficiency. However, there are also segments of population at risk of iron overload. Iron fortification involves complex technological issues, but the economic impact is very high.

Research on "omics" sciences delivers scientific results applicable to the design and production of iron-fortified food.

\section{Keywords}

Iron bioavailability

Food fortification

Iron deficiency

Human nutrition

Omics

Precision nutrition 


\section{Iron deficiency and populations at risk}

Iron deficiency is still the most common and widespread nutritional disorder in the world. Although the estimated 1995-2011 trends in distributions of haemoglobin concentration show that global anaemia prevalence decreased (Stevens et al., 2013), the numbers are still staggering. In 2011, the World Health Organization (WHO) estimated that around 800 million children and women are anaemic, mainly owing to iron deficiency (World Health Organization, 2015). Even though mean blood haemoglobin concentrations and prevalence of anaemia varied substantially across regions (Table 1), iron deficiency is the only nutrient deficiency that is also significantly prevalent in both developing and developed countries. Globally, almost half of the children aged between 6 and 59 months had anaemia, and one in three women of reproductive age was anaemic (World Health Organization, 2015). These data show that iron deficiency and iron deficiency anaemia affect more people than any other condition, and therefore constitute a public health condition of epidemic proportions.

The economic costs of iron deficiency anaemia resulting from annual physical productivity losses have been calculated to be around US $\$ 2.32$ per capita, or $0.57 \%$ of gross domestic product in low- and middle-income countries (Horton \& Ross, 2003). Therefore, iron deficiency and anaemia not only reduce the work capacity of individuals and entire populations but could also bring serious economic consequences and obstacles to national development.

Because of all this, reduction of the global burden of iron deficiency and iron deficiency anaemia is generally considered within the scope of public health nutrition (Pasricha \& Drakesmith, 2016). In fact, in 2012 the World Health Assembly Resolution 65.6 endorsed a "Comprehensive implementation plan on maternal, infant and young child nutrition", which specified six Global Nutrition Targets for 2025 (World Health Organization, 2012), the second target being to "achieve a $50 \%$ reduction of anaemia in women of reproductive age" (World Health Organization, 2014). In this regard, public health strategies to prevent and control anaemia include several options that are currently available for providing iron, but among them iron food fortification seems to present the best risk-benefit balance (Prentice et al., 2017).

In contrast, iron excess is another area of concern since it has been related to several diseases, such as cirrhosis, cardiovascular disease, type 2 diabetes and cancer (Toxqui et al., 2010; Vaquero, García-Quismondo, del Cañizo, \& Sánchez-Muniz, 2017). Therefore, 
subjects at risk of iron overload owing to genetic or acquired diseases should be protected in situations where mass fortification policies are applied.

\section{Functions of iron and consequences of deficiency}

Iron is a metal that is highly abundant in the earth's crust and essential for human life. By the end of the nineteenth century it was acknowledged as a micronutrient needed for recovery from anaemia. Quantitatively, the main biological function of iron is oxygen transport, as it forms part of the haem nucleus in the proteins haemoglobin and myoglobin, but small quantities of iron participate in more than 200 enzymatic systems that are essential for cellular functions (Skikne \& Hershko, 2012), including energy utilization by cells, DNA, RNA and protein synthesis, and numerous redox reactions by virtue of exchanges between the ferrous $\left(\mathrm{Fe}^{2+}\right)$ and ferric $\left(\mathrm{Fe}^{3+}\right)$ states. Iron participates in enzyme systems such as those involved in cholesterol catabolism (Toxqui et al., 2010; Vaquero, García-Quismondo, Cañizo, \& Sánchez-Muniz, 2017), collagen metabolism (Vasta, Higgin, Kersteen, \& Raines, 2013; Vasta \& Raines, 2016), vitamin D activation (Schlingmann et al., 2011), and neurotransmitter metabolism (Hare \& Double, 2016). Therefore, iron is essential for oxygen transport and storage and for many other metabolic functions related to growth, immunity, muscular activity, bone strength and the nervous system.

Iron deficiency is frequently asymptomatic and thus may often go undiagnosed. Nonspecific symptoms ascribed to low delivery of oxygen to body tissues and decreased activity of iron-containing enzymes are weakness, fatigue, tiredness, low work capacity, diminished cognitive efficiency and difficulty in concentrating (Camaschella, 2015). In this regard, it is very well known that an insufficient iron status in the body may negatively affect work performance (Haas \& Brownlie, 2001). In situations of more severe iron deficiency or anaemia there may also be clinical manifestations such as glossitis, angular stomatitis, koilonychia or spoon nails, hair fall and itches (Remacha, 2011). In children and adolescents, lower levels of iron have been linked to growth retardation, a worse motor and cognitive development (Halterman et al., 2001; Grantham-McGregor \& Ani, 2001; McCann \& Ames, 2007; Carter et al., 2010) and social inattention and decreased school performance (Allali et al., 2017). During pregnancy, iron deficiency anaemia has been associated with increased risk of low birth weight, prematurity (Scholl, 2001; Rasmussen, 2001) and maternal and child mortality (Brabin, Hakimi, \& Pelletier, 2001; Brabin, Premji, \& Verhoeff, 2001). Also, a link between iron deficiency and increased risk of bone resorption has been hypothesized in women at childbearing age (Blanco-Rojo et al., 2013; Toxqui et 
al., 2014a; Toxqui \& Vaquero, 2015; Wright et al., 2013). In the elderly, anaemia has been related to decreased quality of life and physical functioning (Thein et al., 2009). Moreover, iron deficiency anaemia has been shown to be an independent risk factor for fatality in patients undergoing surgical procedures (Musallam et al., 2011) and it has been associated with increased all-cause mortality in the general population (Martinsson et al., 2014).

\section{Iron absorption and homeostasis}

As stated earlier, iron is essential for life, but its ability to easily gain or lose electrons also facilitates the generation of highly reactive oxygen species, which would damage essential biological components such as lipids, proteins and DNA (Gozzelino \& Arosio, 2016; Paul \& Lill, 2015). Therefore, it requires a sophisticated regulation that serves to cover the body's demands but also prevents excessive accumulation of iron. Body iron status is maintained by a complex process that regulates the balance between iron absorption in the duodenum, iron recycling by macrophages and iron storage, mainly in the liver, since there is no physiological pathway for iron excretion (Rybinska \& Cairo, 2017). In this regard, hepcidin is shown to play a key role. This hormone, discovered at the beginning of this century, exerts a negative control on iron homeostasis by inhibition of iron absorption and iron mobilization from tissue stores (Ganz \& Nemeth, 2012). Hepcidin acts by binding to and inducing the degradation of ferroportin, an exporter transmembrane protein, inhibiting the release of iron from target cells (hepatocytes, macrophages and enterocytes) (Nemeth et al., 2004). Moreover, recent findings demonstrate that hepcidin may also regulate body iron uptake by decreasing expression of the genes involved in iron absorption (Bergamaschi et al., 2017).

Iron in food is present in two forms: non-haem and haem iron. Non-haem iron present in food is of animal and plant origin, while haem iron is only provided by animal food. Iron is absorbed mainly in the duodenum, but the absorption mechanisms of these forms are different, as presented in Figure 1.

\subsection{Non-haem iron absorption}

Non-haem iron complexes present in food are degraded during digestion in the gastrointestinal tract owing to the action of pepsin and hydrochloric acid. Once released from food components, most non-haem iron is present in the ferric form $\left(\mathrm{Fe}^{3+}\right)$, which has low solubility and bioavailability (Han, 2011). However, there are numerous dietary components capable of reducing $\mathrm{Fe}^{3+}$ to $\mathrm{Fe}^{2+}$, including ascorbic acid, and amino acids 
such as cysteine and histidine, and moreover the main reducing activity is carried out by duodenal cytochrome $b$ reductase (Dcytb), a haemoprotein located on the apical membrane of the enterocyte that uses ascorbate to facilitate ferrireduction (Sharp \& Srai, 2007).

\subsubsection{Ferrous iron absorption}

The soluble $\mathrm{Fe}^{2+}$ form is transported into the enterocyte via the divalent metal transporter-1 (DMT-1), which is a proton symporter requiring low $\mathrm{pH}$ for efficient function for metal transport (Figure 1). This carrier is not iron-specific and there is competition between iron and other divalent metals, such as calcium and zinc (Kordas \& Stoltzfus, 2004).

\subsubsection{Ferric iron absorption}

Some authors have proposed that $\mathrm{Fe}^{3+}$ might be absorbed by intestinal enterocytes via a mechanism that is distinct from DMT-1, although this mechanism has not been totally elucidated (Simovich et al., 2003). It is proposed that luminal $\mathrm{Fe}^{3+}$, by interaction with mucins and subsequent association with $\beta 3$-integrin and mobilferrin, first crosses the luminal membrane and is internalized; then this $\mathrm{Fe}^{3+}$-protein complex combines with flavinmonooxygenase (flavin-MO) and $\beta 2$-microglobulin ( $\beta 2-\mathrm{m})$ to form a paraferritin complex where $\mathrm{Fe}^{3+}$ is reduced to $\mathrm{Fe}^{2+}$ (Sharp, 2010; Simovich et al., 2003), which can finally be exported to the cytosol by DMT-1.

\subsubsection{Ferritin absorption}

It has been hypothesized that ferritin may also be a good source of iron. Three mechanisms have been proposed: ferritin that is taken up by a specific receptor in the luminal membrane; an endocytosis mechanism; or that ferritin provides $\mathrm{Fe}^{3+}$ after protease hydrolysis. It should be noted that ferritin is a macromolecule in which a large quantity of iron is stored (Theil, 2013; Theil et al., 2012), both in animals and plants, thus intense activity exists in this field (Latunde-Dada et al., 2014).

\subsection{Haem iron absorption}

With regard to the haem absorption route, there is a specific haem-carrier protein (HCP1) at the brush border, which explains why this iron form is almost unaffected by dietary factors and mostly absorbed intact. This carrier is also a proton-coupled folate transporter, often called HCP-1/PCFT, that displays higher affinity for folate than haem (Laftah et al., 2009). Once internalized, haem iron is released by haem oxygenase (HO) and then 
follows the same pathways as non-haem iron (Shayeghi et al., 2005) or, as suggested recently, is exported intact through the basolateral membrane by FLVCR1 to the plasma, where it is captured by haemopexin and delivered in the form of haem-haemopexin. This second export mechanism would be a minor pathway and it involves the CD91 receptor of the haem-haemopexin complex (Staroń et al., 2017).

\subsection{Intracellular storage and iron export}

The absorbed iron has two fates, depending on the body's requirements. If the body stores are replete, a significant amount of newly absorbed iron will be stored in the enterocytes as ferritin ( $\mathrm{Fe}^{3+}$ form). Because duodenal enterocyte turnover is very rapid (their lifespan is approximately 3-4 d), most of the ferritin contained inside will be lost by cellular desquamation. On the other hand, if the iron needs of the body are high, most of the iron inside the enterocyte will be transported across the basolateral membrane by ferroportin (FPN), and, after oxidation to $\mathrm{Fe}^{3+}$ by hephaestin, a transmembrane-bound ceruloplasmin homologue, be carried as diferric-transferrin and transported in the bloodstream (Anderson, Frazer, McKie, \& Vulpe, 2002; Garrick \& Garrick, 2009; Lane et al., 2015). When body iron stores are high, ferroportin is inactivated by hepcidin, as this hormone downregulates iron absorption and mobilization from tissues (Gharibzahedi \& Jafari, 2017a).

\section{Iron bioavailability and dietary factors}

The term bioavailability of food components emerged from the phenomenon of the appearance in plasma of orally administered drugs used in pharmacology. In the case of mineral bioavailability, and specifically that of iron, bioavailability was initially synonymous with absorption and it was determined by in vitro solubility. The more soluble the iron compound, the greater its potential absorption and thus its bioavailability. This solubility approach is related to the definition of iron availability, or dialysability, if the digestion process is simulated using a semipermeable membrane and transport through it is measured (Vaquero, 1992).

In parallel with the development of new techniques, either in vitro or in vivo, the concept of bioavailability has developed. Therefore, iron bioavailability is currently defined as the proportion of iron ingested that is absorbed by the intestine and used through normal metabolic pathways or stored. It is expressed as a percentage of intake and is known to be influenced by dietary and host factors (Aggett, 2010), as shown in Figure 2. This wider approach to iron bioavailability includes the following steps: release from its matrix; 
absorption into the systemic circulation; distribution to tissues; metabolic utilization or storage in the body. From the standpoint of Food Science and Technology, the first two are the main ones to consider.

As explained in section 3, the pathway for intestinal haem absorption is independent from those of non-haem iron, and haem iron is almost unaffected by interactions with other food components. However, the haem form only constitutes about 10-15\% of total dietary iron, thus non-haem is the main iron source. There are concerns related to the possible health effects of increasing haem intake to protect from iron deficiency since excess haem intake has been related to colon cancer, increased oxidative status, etc. (Turner \& Lloyd, 2017). Therefore, everything that can be said about enhancers and inhibitors of iron absorption refers to non-haem iron.

\subsection{Dietary components that increase or decrease iron bioavailability}

First of all, the amount of iron ingested is a prerequisite for having bioavailable iron. This seems an obvious statement, but we must emphasize that no matter how powerful an enhancer or inhibitor may be, if it is consumed in a meal where iron is absent, its effect on iron absorption will be null. In this regard, it is also important to remember that interactions in the digestive tract occur within a couple of hours after ingestion. Therefore, the concept of bioavailability as the "proportion" of the iron ingested that is utilized or stored for body functions has to take into account the amount of iron ingested, the meal composition and the time between meals.

Another important factor is the form of iron. As indicated above, the pathway for intestinal haem absorption is independent from that of non-haem, and haem iron is almost unaffected by interactions with other food components. Animal foods such as meat and fish are recognized as good sources of highly available iron partly by means of their haem iron content, which is approximately $40 \%$ of total iron (Monsen et al., 1978). Clearly, a mixed diet supplies mainly non-haem iron, which interacts with dietary enhancers and inhibitors, and it has been estimated that iron bioavailability from a Western diet containing up to $90 \%$ of non-haem iron is approximately $5-15 \%$ (FAO/WHO, 2004).

Ferrous iron has generally been assumed to be better absorbed than ferric iron, but in fact both ions can be efficiently absorbed, provided that they reach the mucosa in a soluble form (Figure 1). The limiting point is solubility, as ferric salts can precipitate when $\mathrm{pH}$ rises from the stomach to the duodenal area. This precipitation can be prevented by complexation of iron with compounds that form absorbable chelates that remain soluble at 
increasing pH (Van Dokkum, 2003). In addition, dietary compounds that reduce iron from ferric to ferrous generally increase bioavailability.

Ascorbic acid and animal tissue are the main enhancers, whereas phytic acid and polyphenols are the main inhibitors. Details of enhancers and inhibitors are presented in Table 2.

\subsubsection{Enhancers}

Ascorbic acid (AA) is recognized as the most powerful iron enhancer. AA acts by forming a chelate with iron at the low $\mathrm{pH}$ of the stomach, which is maintained in the intestine. This prevents interaction of iron with other ligands, such as phytates, that bind iron at a higher $\mathrm{pH}$ (Siegenberg et al., 1991). Some authors suggest that the AA-iron complex is absorbed intact in the duodenum and others indicate that the binding mechanism predominates over the ferrireductase activity of AA (Teucher, Olivares, \& Cori, 2004). Interestingly, AA is a cofactor of Dcytb, the main enzyme that provides $\mathrm{Fe}^{2+}$ from $\mathrm{Fe}^{3+}$ to the enterocyte luminal membrane (Latunde-Dada et al., 2002).

The AA/Fe molar ratio is decisive in the final effect on iron absorption. Our research group studied the influence of consumption of an iron-fortified fruit juice, compared to a placebo fruit juice, in iron-deficient women (Blanco-Rojo et al., 2011b). The AA/Fe ratio was 1.7:1, and a clear increase in iron status was obtained from the first month of the assay. In this regard, several authors proposed a 2:1 ratio for low phytate content foods (Hurrell et al., 2004; Lynch \& Stoltzfus, 2003; Teucher et al., 2004) and up to 4:1 for high phytate content food (Hurrell et al., 2004). However, it should be taken into account that $A A$ is sensitive to temperature and air exposure and that food processing may decrease the concentration of AA by oxidation to dehydroascorbic acid (Teucher et al., 2004).

Animal tissue, from meat, fish or poultry, exerts an enhancing effect on iron absorption. This is a well-known factor, though the precise mechanism of action is still a matter of investigation. Non-haem iron absorption in infants increased if $25 \mathrm{~g}$ of lean beef was included in an $80 \mathrm{~g}$ vegetable purée (Engelmann et al., 1998). Similar results were obtained in young women: the addition of pork meat (50 g or $75 \mathrm{~g}$ ) to a meal presumed to have low iron bioavailability (containing $220 \mathrm{mg}$ of phytic acid and $7.4 \mathrm{mg}$ of ascorbic acid) increased iron absorption significantly (Bæch et al., 2003a). Another study showed that iron absorption doubled with the addition of $60 \mathrm{~g}$ of lean fish to a simple meal consisting of rice, boiled vegetables and curry (Hallberg et al., 1978). Most of the studies were performed using low-fat meat or fish, but Navas-Carretero et al. (2008) tested the possible 
effect of the addition of salmon fish to a high-phytate food. The experiment was aimed at reproducing a meal, red-kidney beans $(80 \mathrm{~g})$ with or without salmon $(100 \mathrm{~g})$, which was spiked with stable isotopes and given to iron-deficient women. The fish contained about $20 \%$ protein, expected to favour bioavailability, and $20 \%$ fat, part of which was n3 unsaturated fat that in high doses was reported to induce alterations in cellular membranes and haemolysis (Pérez-Granados, Vaquero, \& Navarro, 1995). Results showed that the portion of salmon was able to increase iron absorption from the bean meal significantly, suggesting that an adequate combination of enhancers and inhibitors determines the final effect on iron bioavailability (Navas-Carretero et al., 2008).

Cooking temperature does not affect the enhancing effect of animal tissue (Bæch et al., 2003b), although it may decrease the amount of haem iron by degradation into non-haem (Cross et al., 2012; Lombardi-Boccia, Martinez-Dominguez, \& Aguzzi, 2002), with a possible counteracting effect on iron absorption.

There are many doubts about the nature of the iron enhancer in meat and fish, but candidates include peptides rich in cysteine residues and carbohydrate fractions formed during digestion of proteins and glycosaminoglycans of the extracellular matrix of muscle tissues (Armah et al., 2008; Belluzzi et al., 2007; Huh, Hotchkiss, Brouillette, \& Glahn, 2004).

\subsubsection{Inhibitors}

Phytates, myo-inositol phosphates, present in whole-grain cereals and legumes, inhibit non-haem iron absorption, depending on the number of phosphates linked to the inositol ring. Inositol hexaphosphate and inositol pentaphosphate are the most potent iron inhibitors, and the effect is dose-dependent (Hurrell \& Egli, 2010). Phytate:iron molar ratios higher than 1 reduce iron absorption (Hallberg, Brune, \& Rossander, 1989; NavasCarretero et al., 2008).

Since the interaction is due to complexation of iron with the negatively charged phosphate groups of phytate, the use of commercial phytases for dephosphorylation of phytate has been promoted (Nielsen, Tetens, \& Meyer, 2013). These may be produced biotechnologically, but there are still many problems for the application of this technology and its real repercussions, particularly in malnourished populations with iron deficiency.

Polyphenols are a heterogeneous group of plant compounds widely known for their interaction with iron and other metals. There is enormous interest in the development of 
applications with this family of compounds (Khan et al., 2018). The strength of iron chelation depends on the polyphenol structure. It is suggested that at least two hydroxyl groups in the ortho- position are necessary, such as in catechins and gallates. A good example of an iron inhibitor is black tea, and, to a lesser extent, green tea, coffee, chocolate, wine, herbs and spices, and seeds (Hurrell et al., 2010; Navas-Carretero et al., 2007b; Petry, Boy, Wirth, \& Hurrell, 2015). Nevertheless, polyphenols generally exert antioxidant effects, and may protect against chronic diseases, such as diabetes, cardiovascular diseases and several cancer types (Aprotosoaie et al., 2016; Lall et al., 2015; Moyano et al., 2016; Tangney \& Rasmussen, 2013). Therefore, it is important to define the vulnerable population groups and the proper combinations of foods and ingredients to prevent iron deficiency anaemia.

Calcium and other divalent metals interact with iron for DMT-1 transport. Higher consumption of calcium or dairy products is associated with lower iron status. In a randomized controlled trial, consumption of a milk product fortified with iron that provided $100 \%$ of the recommended daily iron intake did not improve iron status during four months in iron-deficient women. The effect was attributed to the presence of calcium and partly also casein, which behaved as inhibitors, and the absence of iron enhancers in the product (Toxqui et al., 2013). Zinc in excess has also been reported to reduce iron absorption, and vice versa, an interaction that may be particularly relevant in pregnancy and infancy (lyengar, Pullakhandam, \& Nair, 2010; Pérès et al., 1998).

Several reports indicate that, compared to linoleic acid and polyunsaturated fatty acids, saturated fat increases iron bioavailability (Lukaski et al., 2001; Miret, Saiz, \& Mitjavila, 2003; Pérez-Granados et al., 1995). The mechanism may act mostly after absorption (Vaquero, García-Quismondo, del Cañizo, \& Sánchez-Muniz, 2017). It seems that an n6:n3 fatty acids unbalance induces metabolic alterations, including lipid peroxidation and changes in erythrocyte membrane composition, leading to haemolysis, iron depletion and anaemia (Pérez-Granados et al., 1995; Vaquero, Veldhuizen \& Sarriá, 2001).

\section{Dietary reference values for iron}

Iron provided by the diet should be enough to meet physiological requirements and cover iron losses, ensuring a good iron status (Vaquero, 2011). The methodology for calculating dietary reference values for iron is complex, since it is necessary to determine both the requirements for each population group, according to physiological needs and iron losses; and a factor or ratio of intestinal iron absorption, which depends on the diet 
consumed, as explained in section 4, and on the iron status and genetic background of the subject (Institute of Medicine, 2001).

Physiological iron needs depend on the individual's life stage. In infants, children and adolescents the mineral is required for haemoglobin mass increase, synthesis of new tissues and an increase in storage iron to build a reserve (Berglund \& Domellöf, 2014; Domellöf et al., 2014; Mesías, Seiquer, \& Navarro, 2013). Throughout the course of pregnancy, iron demands increase due to foetal growth and the expansion of plasma and blood volumes in the mother (McMahon, 2010; Vricella, 2017).

Iron losses in all population groups include loss of the mineral in faeces (physiologically regulated), and minor losses in urine and sweat and from exfoliation of skin cells. In women of child-bearing age, menstrual blood loss may constitute a relatively high iron loss (Hunt, Zito, \& Johnson, 2009). In this regard, although there are several studies that show a relationship between the duration of the menstrual period and the volume of menstrual losses and serum ferritin, it is considered that the distribution is biased and difficult to estimate (Blanco-Rojo et al., 2014; Harvey et al., 2005; Toxqui et al., 2014b).

With regard to iron absorption, it is well known that it is highly dependent on the physiological situation and the iron status of the individual. In healthy subjects, intestinal absorption of dietary iron is inversely related to serum ferritin concentrations, particularly at concentrations below $60 \mu \mathrm{g} / \mathrm{L}$ (Ganz, 2013). Also, in pregnant women the increased need for iron is shown to be met by increases in the efficiency of iron absorption (Fisher \& Nemeth, 2017). Moreover, genetic variants related to iron metabolism could increase iron absorption (Sarria et al., 2007; Ye et al., 2015). On the other hand, in situations of infection iron absorption decreases as part of the responses of the immune system to avoid proliferation of infection and sepsis (Cassat \& Skaar, 2013).

Therefore, both the complexity and the variability of the various factors involved in iron homeostasis would partly explain why there is no consensus in the Recommended Dietary Allowance (RDA) of iron given by several countries and organizations, as is shown in Table 3. In summary, the highest recommended values for iron are for women of childbearing age (except for Brazil) and pregnant women, and the FAOMHO recommendations point out the importance of dietary iron bioavailability (Brasil, 2005; European Food Safety Authority, 2015; Institute of Medicine, 2001; FAO/WHO, 2002; Nordic Council of Ministers, 2014; Moreiras, Carbajal, Cabrera, \& Cuadrado, 2016; Department of Health UK, 1991). 
On the other hand, the redox activity of iron makes it potentially toxic if it is present in excess. The main adverse effects that have been described are: acute toxicity, iron-zinc interactions, gastrointestinal discomfort, secondary iron overload (Institute of Medicine, 2002), and chronic diseases (Vaquero, García-Quismondo, del Cañizo, \& Sánchez-Muniz, 2017; Institute of Medicine, 2002). However, not all the countries or organizations that have given a RDA have determined a Tolerable Upper Intake Level (UL). The European Food Safety Authority (EFSA) considered that the risk of systemic iron overload from dietary sources is negligible with a normal intestinal function, and the adverse effects described are secondary to an overdose of medical iron (European Food Safety Authority, 2015). Only the Institute of Medicine (IOM) has established a UL for iron in adults (45 $\mathrm{mg} /$ day for males and females aged 14 years and older, including pregnant and lactating women) and for infants and children (40 mg/day) (Institute of Medicine, 2001).

\section{The challenge of iron fortification}

Iron is the most difficult micronutrient to add to produce fortified food. A variety of iron salts have been tested and incorporated into different dietary matrices with the aim of producing iron-fortified foods according to the needs of the target population. Ferrous sulfate is widely accepted as the reference salt in studies of bioavailability; it is cheap and efficiently absorbed, but its main disadvantages are that it is quite unstable, its oxidation depending on temperature and air exposure, and it may produce adverse organoleptic changes (Huma et al., 2007). Oxidation may alter other food components and modify the colour of the vehicle's food, with the result of lower product quality, adverse sensory properties and consequently poor acceptance. The technological challenge is to achieve an iron form that, when added in sufficient quantity, provides enough bioavailability to improve iron status, and that is not rejected owing to sensory changes or adverse gastrointestinal effects. Moreover, although iron fortification is a more cost-effective strategy than iron supplementation (e.g. pharmaceutical iron) for the prevention of iron deficiency anaemia in populations at risk, the cost may be unaffordable for vulnerable individuals (Hurrell et al., 2004).

Iron fortification can be classified into three types: mass fortification, target fortification, and market-driven fortification. The first one is intended to protect the general population from deficiency and is common in developing countries, the second is limited to special population groups, and the third is the result of a manufacturer initiative intended to commercialize an enriched food with added value that would satisfy consumer choice. This 
last type is usual in developed countries and can be a practical option in the improvement of public health or segments of population, e.g. athletes, vegetarians, etc.

The efficacy of iron fortification in the improvement of iron status depends on many factors, such as the vehicle selected, the iron compound and the iron status of the target population group.

\subsection{Iron fortificants}

Numerous fortificants are available for iron fortification. The biggest challenge is to identify a form of iron compound that is adequately absorbed, is stable, and does not alter the appearance or taste of the food vehicle.

Table 4 shows some of the iron fortificants that are widely used, together with newly proposed fortificants. Aspects such as solubility should be balanced with others such as feasibility of application in the real situation and desired bioavailability. In this regard, it may be preferable to choose a compound with lower iron bioavailability but that can be added to the food in greater quantity without organoleptic side effects.

Research on new iron fortificants is very active. The EFSA concluded that the following iron sources are of no safety concern: ferrous bisglycinate (European Food Safety Authority, 2006); ferric sodium EDTA, as long as it does not lead to an exposure to EDTA above $1.9 \mathrm{mg}$ EDTA/kg body weight/day (European Food Safety Authority, 2010); iron (II) taurate (European Food Safety Authority, 2009); and iron L-pidolate (European Food Safety Authority, 2007).

In contrast, haem iron has not been proved to be safe, and in fact there are concerns about its use, as excess intake of haem has been related to colorectal and prostate cancer (Bylsma \& Alexander, 2015; Fonseca-Nunes, Jakszyn, \& Agudo, 2013; Span et al., 2016) Therefore, until all doubts are cleared, its use in fortification should be discarded.

As shown in Figure 3, strategies to increase bioavailability include reduction of particle size and encapsulation (Genevois, de Escalada Pla, \& Flores, 2016). Micronized ferric pyrophosphate, commercialized in liquid and dried forms, has been tested in the last decade. Being insoluble in water, this fortificant does not produce colour changes in the food matrix or cause sensory changes. Reduction of its mean particle size from 8 to 4 microns increased iron absorption by 2-4 times in adults (Hurrell et al., 2004).

\subsection{Food vehicle}


In the design of iron-fortified food it is necessary to select the appropriate combination of fortificant and vehicle, taking into account the individuals that will benefit from its consumption. In this regard, powder infant formulas represent a successful example. Generally, they contain ferrous sulfate, which is $100 \%$ soluble when the formula is reconstituted, and ascorbic acid, which guarantees sufficient iron bioavailability (ShamahLevy et al., 2008; Villalpando et al., 2006). Cereal foods, for the weaning stage or adulthood, are good candidates for fortification as they are staple foods in many populations around the world and can be handled in solid form to manufacture the ironfortified cereal-based food. The iron compounds recommended by the WHO to fortify cereals are ferrous sulfate, ferrous fumarate, ferric pyrophosphate and electrolytic iron (Diego Quintaes, Barberá, \& Cilla, 2017). Another aspect to be taken into account is cooking or industrial thermal processing, because these treatments may decrease iron bioavailability by modification of the fortificant itself or the accompanying food components (Lee, Clydesdale, \& Tannenbaum, 1979).

Food matrix composition is decisive to ensure the efficacy of iron fortification (Figure 3). In this line, our research group studied the effects of consumption of a fruit juice fortified with microencapsulated iron pyrophosphate coated with lecithin on iron status in a target population. We performed a 16-week randomized double-blind placebo-controlled trial in iron-deficient young women (Blanco-Rojo et al., 2011b). Women were randomly assigned to the iron-fortified group or the placebo group. Both fortified and placebo juices were manufactured in $500 \mathrm{~mL}$ cartons and with two different flavours (orange and peach-apple) to achieve compliance. The iron-fortified juice provided $18 \mathrm{mg}$ of iron (100\% of the RDA per day, $500 \mathrm{~mL} /$ day). It was found that the iron-fortified juice induced an improvement in iron status, with significant increases in haemoglobin, haematocrit, mean corpuscular volume, serum ferritin, and transferrin saturation; and decreases in serum transferrin and soluble transferrin receptor. Therefore, it was concluded that consumption of this iron form in this particular food matrix was efficacious in improving iron bioavailability in irondeficient women (Blanco-Rojo et al., 2011b).

However, the same iron form (microencapsulated iron pyrophosphate), using the same amount per day and given to a group of iron-deficient women $(n=109)$ with characteristics very similar to those of the previous investigation, was not efficacious when added to a dairy product (Toxqui et al., 2013). These contrary results were explained by the different food matrices. The iron-fortified fruit juice contained a high quantity of ascorbic acid, which 
favours iron absorption, whereas the dairy product contained $600 \mathrm{mg}$ of calcium per $15 \mathrm{mg}$ of iron, known to be an inhibitor of iron bioavailability if consumed in a meal that does not contain absorption enhancers.

In this regard, other findings by our research group reinforce the importance of the food vehicle. Encapsulated iron pyrophosphate was demonstrated to be bioavailable when added to a meat pâté (Navas-Carretero et al., 2007a; Navas-Carretero, Pérez-Granados, Sarriá, \& Vaquero, 2009), but not if included in cocoa powder (Navas-Carretero et al., 2007b). Although encapsulation was intended to protect the iron from interactions with other food components, thus maintaining bioavailability, experimental results in animal and human models demonstrated that, no matter how good the iron fortificant may be, its intake in combination with enhancers and inhibitors determines the final effect (Shilpashree, Arora, Sharma, \& Singh, 2015).

\subsection{New strategies for iron fortification}

New iron fortificants are under development. Nanotechnology engineering provides nanosized iron that can be highly absorbed by physiological routes (Gharibzahedi \& Jafari, 2017b). However, because excess free iron in biological systems is harmful, maximum safety conditions are required before industrial production (Mahler et al., 2012). We observed in an animal model that Fe (III) oxide nanoparticulates were absorbed by the ferric pathway and did not cause adverse haematological or organ effects (Chamorro et al., 2015), suggesting that it is feasible to produce customized iron forms and fractions with the objective of controlling iron solubility and absorption as desired.

Ferritin nanoparticles are another option. Biologically, ferritin is a large protein capable of storing high amounts of iron and, as mentioned in section 3 , it may be a good source of iron, although the exact mechanism of absorption is unknown. Thus synthetic ferritinmimetic nanoparticulates have been developed and studied in isolated duodenal loops or cultured cells (Aslam et al., 2014; Latunde-Dada et al., 2014).

With regard to, the food vehicles to be fortified with iron, apart from infant formula and staple foods, seasonings (i.e. table salt, soy sauce, fish sauce, bouillon and curry powder) have been assayed owing to their extensive use in the various target populations (Degerud, Manger, Strand, \& Dierkes, 2015). The steps in the industrial production of micronutrient-fortified condiments and seasonings have been reported (Mejia, AguileraGutiérrez, Martin-Cabrejas, \& Mejia, 2015). Reports indicate that consumption of 
NaFeEDTA in a sauce (World Health Organization, 2006) decreased the prevalence of anaemia in India and China. Electrolytic elemental iron added to curry powder has also been assayed (Karn, Chavasit, Kongkachuichai, \& Tangsuphoom, 2011). Likewise, the fortification of bouillon cubes seems promising (Cercamondi et al., 2016). Moreover, combinations with probiotics have been proposed to increase bioavailability (Hoppe, Onning, Berggren, \& Hulthen, 2015).

Biofortification, i.e. breeding and genetic modification of plants to obtain a final plant food with a higher iron content, is another approach for which there are high expectations. Efforts have been made with micronutrient biofortification in staple foods, but the final objectives are still far from being accomplished and all requirements related to safety, cost-benefit and low environmental impact should be fulfilled before implementation (Finkelstein, Haas, \& Mehta, 2017; Petry et al., 2015; Ramzani et al., 2016).

\section{Current trends in iron research. "Omics" and Precision Nutrition}

Since ancient times it has been observed that individuals respond differently to diet and environmental factors. But it was not until the end of the twentieth century, when the sequencing of the human genome was completed, that a new research field emerged, Nutritional Genomics, which aimed at discovering how genetic variations could modulate the effect of certain diets or nutrients on different phenotypes (nutrigenetics). At the same time, this discipline also pursued the study of how dietary components may influence gene expression and metabolic routes (nutrigenomics) (Ordovas \& Corella, 2004). Current technological advances have allowed the discovery of other "omics" that also interact with dietary factors to influence individual responses and metabolism. Thus, nutriepigenetics refers to the effect of certain nutrients or diets in reversing epigenetic alterations, relating to gene expression without concomitant changes in the DNA coding sequence, which might have a significant impact on preventing and treating chronic human diseases (Choi et al., 2013). Another concept is metagenomics, which is related to the interaction between gut microbiota, diet and various metabolic processes (Ferguson et al., 2016).

These "omics-based" investigations have also reached the field of iron research. Several studies have shown how iron metabolism can be modulated by genetic variations affecting the corresponding proteins. Among them, the best-known and most widespread genetic variants are two related to susceptibility to iron overload located in the HFE gene, C282Y and H63D mutations (Merryweather-Clarke et al., 2000). These polymorphisms result in diminished expression of hepcidin, which leads to a failure to downregulate the 
efflux of iron absorbed from enterocytes when iron stores are replete or excessive, therefore causing iron accumulation and potential tissue damage, a disorder also known as haemochromatosis (Fleming et al., 2005). Less common mutations in haemojuvelin, hepcidin, transferrin-2 and ferroportin genes also occur and, through a deficiency of or resistance to hepcidin, also result in unregulated iron absorption and efflux from the enterocyte, leading to iron overload and tissue damage (Brissot et al., 2017). However, these variants could be considered as an advantage for certain populations, such as women at childbearing age, which have high susceptibility to iron deficiency due to menstrual losses. Indeed, high iron status was observed in heterozygous young women, for either C282Y or H63D, compared with women lacking these mutations (Blanco-Rojo et al., 2011a; Blanco-Rojo et al., 2014; Gordeuk \& Brannon, 2017). On the other hand, other mutations have been related to iron deficiency. Several TMPRSS6 mutations may increase systemic hepcidin levels in humans, leading to iron-deficiency anaemia (Beutler et al., 2010). Also, mutations in the transferrin (TF) gene, the calcium channel gene (CACNA2D3) and the HIST1H2BJ gene have been associated with low iron status in irondeficient young women (Baeza-Richer et al., 2015; Baeza-Richer et al., 2013; Blanco-Rojo et al., 2011a).

Moreover, the best documented examples of clinically significant nutrigenetic interactions are those concerning the HFE mutation C282Y. Iron absorption from isotopically labelled iron dosages and test meals was repeatedly reported to be higher in subjects who were homozygous or heterozygous for the C282Y mutation than in healthy control individuals (Hunt \& Zeng, 2004; Hutchinson et al., 2008; Roe et al., 2005). Also, both longitudinal and cross-sectional iron intervention studies showed interactions between dietary components, HFE genotype and iron status (Greenwood et al., 2005; Kaltwasser et al., 1998; Milward et al., 2008; Scotet et al., 2003). However, investigations about other genes involved in iron homeostasis and diet interactions are scarce, particularly those related to iron deficiency anaemia, and the results are less clear. Sarria et al. (2007) found no influence of mutation G277S in the TF gene on iron absorption in iron-deficient women. Cheng et al. (2014) observed that women with the minor allele of the TMPRSS6 rs855791 polymorphism presented higher serum iron and transferrin saturation compared to $\mathrm{T}$ subjects after a 12-month trial with a higher-protein, higher-haem iron weight loss diet. Moreover, in a placebo-controlled nutritional intervention with an ironfortified fruit juice in iron-deficient women, Blanco-Rojo et al. (2010) showed that the iron- 
fortified juice markedly increased iron status, except in women that presented the minor allele of SNP rs3811647 located in the TF gene.

With regard to epigenomics, cells have several mechanisms that specifically regulate the expression of iron metabolism-related genes. These include the modulation of general cellular mechanisms that give rise to alternative transcript variants (such as alternative transcription initiation, polyadenylation and splicing) or of more specific systems that control the stability of the mRNAs and proteins (Silva \& Faustino, 2015). In this regard, it was recently suggested that non-coding microRNAs (or miRNAs) may be implicated in iron metabolism regulation, as well as in the development of iron-related disorders (Davis \& Clarke, 2013). These miRNAs normally repress gene expression and exert their function by binding to the target mRNA and consequent translation inhibition and/or degradation (Eulalio, Huntzinger, \& Izaurralde, 2008). Several miRNAs involved in iron metabolism were widely reviewed by Davis and Clarke (2013) and Silva and Faustino (2015), who described miRNAs implicated in dietary iron absorption, cellular iron uptake and systemic control of iron homeostasis.

In addition, it has been suggested that a bidirectional relationship exists between the host iron intake and gut microbiota (Deschemin et al., 2016). It is well known that the amount of iron ingested (by diet or supplements) directly influences the composition of the microbiota (Bullen, Rogers, Spalding, \& Ward, 2005). Accumulating evidence suggests that unabsorbed iron can stimulate growth and virulence of bacterial pathogens in the intestinal environment (Dostal et al., 2014; Jaeggi et al., 2015), although it has also been proposed that the iron status of the host and susceptibility to gut inflammation could play a role in the changes observed in gut microbiota composition (Buhnik-Rosenblau, MosheBelizowski, Danin-Poleg, \& Meyron-Holtz, 2012). On the other hand, a recent study in mice demonstrated that microbial colonization of the gut has an impact on the intestinal proteins involved in iron metabolism, so gut microbiota may affect the iron status of the host by interacting with iron transport by enterocytes and subsequent exportation and storage (Deschemin et al., 2016).

The scientific background in this field should be considered when a fortification programme is planned. In this regard, iron fortification altered gut microbiota of Kenyan infants, increasing pathogen abundance and causing intestinal inflammation (Jaeggi et al., 2015). Other reports indicate that iron fortification, independently of the iron source used, can increase diarrhoea incidence in low-income countries (Paganini \& Zimmermann, 
2017). The strategy in these cases has to achieve a balance between the iron level and the provision of other micronutrients together with medical care. The use of probiotics in iron fortification is also being explored. Hoppe et al. (2015) observed that in a group of menstruating women the addition of Lactobacillus plantarum increased iron absorption from an iron-fortified fruit drink by approximately 50\%. In another study (Paganini et al., 2017), galacto-oligosaccharides added to a low dose of iron fortificant reduced most of the negative intestinal effects in malnourished infants. Thus, probiotics included in the fortified food may alleviate possible adverse effects on the gut microbiome (Paganini et al., 2017) and perhaps may have additional benefits, such as reduction of the iron cost and health effects.

All these advances in "omics" sciences, and their reported effect on iron homeostasis, may add a new level in iron dietary recommendations and may involve the customization of iron-fortified products to increase benefits for individuals, thus expanding into more effective public health strategies on iron fortification. Although further investigations on the interactions in "omics" sciences are needed, we are on the path of change, moving from traditional recommendations to Precision Nutrition (Ferguson et al., 2016).

\section{Conclusions}

In the design of iron-fortified food it is important to delineate the main factors involved. Clearly there is a social demand, as iron deficiency is by far the most widespread nutritional deficiency, so the number of potential consumers is enormous. In this context, at present recommendations tailored for specific groups according to precision nutrition concepts are increasing. The selection of the iron to be used as fortificant and innovation in searching for new fortificants are the main manufacturing aspects. If a traditional compound such as iron sulfate or elemental iron can be used, possibly the cost of its production is the lowest, but cost calculations should be related to a reference bioavailability value, because very cheap iron fortificants may need double or triple the amount to have the same bioavailability as other forms. Moreover, safety has to be proved firstly in vitro or in animal models, and, if positive results are obtained, later the ironfortified food should be tested in human subjects. The target population has to be protected against iron deficiency and also against overload and side effects.

The interactions between the iron fortificant, the food vehicle and the consumer deserve a multidisciplinary approach. Further studies should be done on these aspects, with 
participation of experts such as food scientists, technologists, manufacturers, nutritionists, geneticists, biotechnologists and public health professionals.

\section{Acknowledgements}

This research did not receive any specific grant from funding agencies in the public, commercial or not-for-profit sectors. 


\section{References}

Aggett, P. J. (2010). Population reference intakes and micronutrient bioavailability: a European perspective. The American Journal of Clinical Nutrition, 91(5), 1433S-1437S.

Allali, S., Brousse, V., Sacri, A. S., Chalumeau, M., \& de Montalembert, M. (2017). Anemia in children: prevalence, causes, diagnostic work-up, and long-term consequences. Expert Review Hematol, 10(11), 1023-1028.

Anderson, G. J., Frazer, D. M., McKie, A. T., \& Vulpe, C. D. (2002). The ceruloplasmin homolog hephaestin and the control of intestinal iron absorption. Blood Cells, Molecules, \& Diseases, 29(3), 367-375.

Aprotosoaie, A. C., Miron, A., Trifan, A., Luca, V. S., \& Costache, I.-I. (2016). The Cardiovascular Effects of Cocoa Polyphenols-An Overview. Diseases, 4(4), 39.

Armah, C. N., Sharp, P., Mellon, F. A., Pariagh, S., Lund, E. K., Dainty, J. R., Teucher, B., \& Fairweather-Tait, S. J. (2008). L- $\alpha$-glycerophosphocholine contributes to meat's enhancement of nonheme iron absorption. Journal of Nutrition, 138(5), 873-877.

Aslam, M. F., Frazer, D. M., Faria, N., Bruggraber, S. F. A., Wilkins, S. J., Mirciov, C., Powell, J. J., Anderson, G. J., \& Pereira, D. I. A. (2014). Ferroportin mediates the intestinal absorption of iron from a nanoparticulate ferritin core mimetic in mice. The FASEB Journal, 28(8), 36713678.

Bæch, S. B., Hansen, M., Bukhave, K., Jensen, M., Sørensen, S. S., Kristensen, L., Purslow, P. P., Skibsted, L. H., \& Sandström, B. (2003a). Nonheme-iron absorption from a phytate-rich meal is increased by the addition of small amounts of pork meat. The American Journal of Clinical Nutrition, 77(1), 173-179.

Bæch, S. B., Hansen, M., Bukhave, K., Kristensen, L., Jensen, M., Sørensen, S. S., Purslow, P. P., Skibsted, L. H., \& Sandström, B. (2003b). Increasing the cooking temperature of meat does not affect nonheme iron absorption from a phytate-rich meal in women. Journal of Nutrition, 133(1), 94-97.

Baeza-Richer, C., Arroyo-Pardo, E., Blanco-Rojo, R., Toxqui, L., Remacha, A., Vaquero, M. P., \& López-Parra, A. M. (2015). Genetic contribution to iron status: SNPs related to iron deficiency anaemia and fine mapping of CACNA2D3 calcium channel subunit. Blood Cells Mol Dis, 55(4), 273-280.

Baeza-Richer, C., Blanco-Rojo, R., López-Parra, A. M., Brichs, A., Bertoncini, S., Pérez-Granados, A. M., Buil, A., Soria, J. M., Arroyo-Pardo, E., \& Vaquero, M. P. (2013). Identification of a 
novel quantitative trait nucleotype related to iron status in a calcium channel gene. Disease Markers, 34(2), 121-129.

Beck, K., Conlon, C. A., Kruger, R., Coad, J., \& Stonehouse, W. (2011). Gold kiwifruit consumed with an iron-fortified breakfast cereal meal improves iron status in women with low iron stores: a 16-week randomised controlled trial. British Journal of Nutrition, 105(1), 101-109.

Belluzzi, A., Roda, G., Tonon, F., Soleti, A., Caponi, A., Tuci, A., Roda, A., \& Roda, E. (2007). A new iron free treatment with oral fish cartilage polysaccharide for iron deficiency chronic anemia in inflammatory bowel diseases: A pilot study. World Journal of Gastroenterology: WJG, 13(10), 1575.

Bergamaschi, G., Di Sabatino, A., Pasini, A., Ubezio, C., Costanzo, F., Grataroli, D., Masotti, M., Alvisi, C., \& Corazza, G. R. (2017). Intestinal expression of genes implicated in iron absorption and their regulation by hepcidin. Clinical Nutrition, 36(5), 1427-1433.

Berglund, S., \& Domellöf, M. (2014). Meeting iron needs for infants and children. Current Opinion in Clinical Nutrition \& Metabolic Care, 17(3), 267-272.

Beutler, E., Van Geet, C., te Loo, D. M., Gelbart, T., Crain, K., Truksa, J., \& Lee, P. L. (2010). Polymorphisms and mutations of human TMPRSS6 in iron deficiency anemia. Blood Cells Mol Dis, 44(1), 16-21.

Blanco-Rojo, R., Pérez-Granados, A. M., Toxqui, L., Zazo, P., de la Piedra, C., \& Vaquero, M. P. (2013). Relationship between vitamin D deficiency, bone remodelling and iron status in iron-deficient young women consuming an iron-fortified food. European Journal of Nutrition, 52(2), 695-703.

Blanco-Rojo, R., Baeza-Richer, C., López-Parra, A. M., Pérez-Granados, A. M., Brichs, A., Bertoncini, S., Buil, A., Arroyo-Pardo, E., Soria, J. M., \& Vaquero, M. P. (2011a). Four variants in transferrin and HFE genes as potential markers of iron deficiency anaemia risk: an association study in menstruating women. Nutrition \& Metabolism (Lond), 8, 69.

Blanco-Rojo, R., Maria Pérez-Granados, A., López-Parra, A. M., Baeza, C., Bertoncini, S., ArroyoPardo, E., \& Vaquero, P. (2010). Variants in transferrin gene affect iron metabolism and response to an iron supplemented food in menstruating women. Journal of Nutrigenetics and Nutrigenomics, 3, 72.

Blanco-Rojo, R., Pérez-Granados, A. M., Toxqui, L., González-Vizcayno, C., Delgado, M. A., \& Vaquero, M. P. (2011b). Efficacy of a microencapsulated iron pyrophosphate-fortified fruit 
juice: a randomised, double-blind, placebo-controlled study in Spanish iron-deficient women. British Journal of Nutrition, 105(11), 1652-1659.

Blanco-Rojo, R., Toxqui, L., López-Parra, A. M., Baeza-Richer, C., Pérez-Granados, A. M., ArroyoPardo, E., \& Vaquero, M. P. (2014). Influence of diet, menstruation and genetic factors on iron status: a cross-sectional study in Spanish women of childbearing age. International Journal of Molecular Sciences, 15(3), 4077-4087.

Brabin, B. J., Hakimi, M., \& Pelletier, D. (2001). An analysis of anemia and pregnancy-related maternal mortality. Journal of Nutrition, 131(2S-2), 604S-614S; discussion 614S-615S.

Brabin, B. J., Premji, Z., \& Verhoeff, F. (2001). An analysis of anemia and child mortality. Journal of Nutrition, 131(2S-2), 636S-645S; discussion 646S-648S.

Brasil (2005). Resolução ANVISA/MS RDC no 269, de 22 de setembro de 2005. Regulamento técnico sobre a Ingestão Diária Recomendada (IDR) de proteína, vitaminas e minerais. Diário Oficial da União, Brasília, DF, 23 set. 2005.

Brissot, P., Cavey, T., Ropert, M., Guggenbuhl, P., \& Loréal, O. (2017). Genetic hemochromatosis: Pathophysiology, diagnostic and therapeutic management. La Presse Médicale, 46(12 Pt 2), e288-e295.

Brune, M., Rossander-Hultén, L., Hallberg, L., Gleerup, A., \& Sandberg, A.-S. (1992). Iron absorption from bread in humans: inhibiting effects of cereal fiber, phytate and inositol phosphates with different numbers of phosphate groups. Journal of Nutrition, 122(3), 442-449.

Buhnik-Rosenblau, K., Moshe-Belizowski, S., Danin-Poleg, Y., \& Meyron-Holtz, E. G. (2012). Genetic modification of iron metabolism in mice affects the gut microbiota. Biometals, 25(5), 883892.

Bullen, J. J., Rogers, H. J., Spalding, P. B., \& Ward, C. G. (2005). Iron and infection: the heart of the matter. FEMS Immunology and Medical Microbiology, 43(3), 325-330.

Bylsma, L. C., \& Alexander, D. D. (2015). A review and meta-analysis of prospective studies of red and processed meat, meat cooking methods, heme iron, heterocyclic amines and prostate cancer. Nutrition Journal, 14(1), 125.

Camaschella, C. (2015). Iron-deficiency anemia. New England Journal of Medicine, 372(19), 18321843.

Carter, R. C., Jacobson, J. L., Burden, M. J., Armony-Sivan, R., Dodge, N. C., Angelilli, M. L., Lozoff, B., \& Jacobson, S. W. (2010). Iron deficiency anemia and cognitive function in infancy. Pediatrics, 126(2), e427-434. 
Cassat, J. E., \& Skaar, E. P. (2013). Iron in infection and immunity. Cell Host Microbe, 13(5), 509519.

Cercamondi, C. I., Duchateau, G. S., Harika, R. K., van den Berg, R., Murray, P., Koppenol, W. P., Zeder, C., Zimmermann, M. B., \& Moretti, D. (2016). Sodium pyrophosphate enhances iron bioavailability from bouillon cubes fortified with ferric pyrophosphate. British Journal of Nutrition, 116(3), 496-503.

Chamorro, S., Gutierrez, L., Vaquero, M. P., Verdoy, D., Salas, G., Luengo, Y., Brenes, A., \& Jose Teran, F. (2015). Safety assessment of chronic oral exposure to iron oxide nanoparticles. Nanotechnology, 26(20), 205101.

Cheng, H. L., Hancock, D. P., Rooney, K. B., Steinbeck, K. S., Griffin, H. J., \& O’Connor, H. T. (2014). A candidate gene approach for identifying differential iron responses in young overweight women to an energy-restricted haem iron-rich diet. European Journal of Clinical Nutrition, 68(11), 1250-1252.

Choi, S. W., Claycombe, K. J., Martinez, J. A., Friso, S., \& Schalinske, K. L. (2013). Nutritional epigenomics: a portal to disease prevention. Advances in Nutrition, 4(5), 530-532.

Cross, A. J., Harnly, J. M., Ferrucci, L. M., Risch, A., Mayne, S. T., \& Sinha, R. (2012). Developing a heme iron database for meats according to meat type, cooking method and doneness level. Food \& Nutrition Sciences, 3(7), 905.

Davidsson, L., Kastenmayer, P., Szajewska, H., Hurrell, R. F., \& Barclay, D. (2000). Iron bioavailability in infants from an infant cereal fortified with ferric pyrophosphate or ferrous fumarate. American Journal of Clinical Nutrition, 71(6), 1597-1602.

Davis, M., \& Clarke, S. (2013). Influence of microRNA on the maintenance of human iron metabolism. Nutrients, 5(7), 2611-2628.

Degerud, E. M., Manger, M. S., Strand, T. A., \& Dierkes, J. (2015). Bioavailability of iron, vitamin A, zinc, and folic acid when added to condiments and seasonings. Annals of the New York Academy of Sciences, 1357(1), 29-42.

Department of Health UK (1991). Dietary reference values for food energy and nutrients for the United Kingdom: HM Stationery Office.

Deschemin, J. C., Noordine, M. L., Remot, A., Willemetz, A., Afif, C., Canonne-Hergaux, F., Langella, P., Karim, Z., Vaulont, S., Thomas, M., \& Nicolas, G. (2016). The microbiota shifts the iron sensing of intestinal cells. FASEB Journal, 30(1), 252-261. 
Diego Quintaes, K., Barberá, R., \& Cilla, A. (2017). Iron bioavailability in iron-fortified cereal foods: The contribution of in vitro studies. Critical Reviews in Food Science and Nutrition, 57(10), 2028-2041.

Domellöf, M., Braegger, C., Campoy, C., Colomb, V., Decsi, T., Fewtrell, M., Hojsak, I., Mihatsch, W., Molgaard, C., Shamir, R., Turck, D., van Goudoever, J., ESPGHAN Committee on Nutrition. (2014). Iron requirements of infants and toddlers. Journal of Pediatrics, Gastroenterology and Nutrition, 58(1), 119-129.

Dostal, A., Baumgartner, J., Riesen, N., Chassard, C., Smuts, C. M., Zimmermann, M. B., \& Lacroix, C. (2014). Effects of iron supplementation on dominant bacterial groups in the gut, faecal SCFA and gut inflammation: a randomised, placebo-controlled intervention trial in South African children. British Journal of Nutrition, 112(4), 547-556.

Engelmann, M. D., Davidsson, L., Sandström, B., Walczyk, T., Hurrell, R. F., \& Michaelsen, K. F. (1998). The influence of meat on nonheme iron absorption in infants. Pediatric Research, 43(6), 768-773.

Eulalio, A., Huntzinger, E., \& Izaurralde, E. (2008). Getting to the root of miRNA-mediated gene silencing. Cell, 132(1), 9-14.

European Food Safety Authority (2006). Opinion of the Scientific Panel on food additives, flavourings, processing aids and materials in contact with food (AFC) related to Ferrous bisglycinate as a source of iron for use in the manufacturing of foods ad in food supplements. EFSA Journal, 4(1), 299-n/a.

European Food Safety Authority (2007). Opinion of the Scientific Panel on food additives, flavourings, processing aids and materials in contact with food (AFC) related to Calcium, iron, magnesium, potassium and zinc L-pidolate as sources for calcium, iron, magnesium, potassium and zinc added for nutritional purposes to food supplements and to foods intended for particular nutritional uses. EFSA Journal, 5(6), 495-n/a.

European Food Safety Authority (2009). Iron (II) taurate, magnesium taurate and magnesium acetyl taurate as sources of iron or magnesium added for nutritional purposes in food supplements. EFSA Journal, 7(2), 947-n/a.

European Food Safety Authority (2015). Scientific Opinion on Dietary Reference Values for iron. EFSA Journal, 13(10), 4254-n/a.

European Food Safety Authority (2010). Scientific Opinion on the use of ferric sodium EDTA as a source of iron added for nutritional purposes to foods for the general population 
(including food supplements) and to foods for particular nutritional uses. EFSA Journal, $8(1), 1414-n / a$.

FAO/WHO. Human vitamin and mineral requirements. Report of a Joint FAO/WHO Expert Consultation Bangkok, Thailand. Rome (2002). http://www.fao.org/docrep/ 004/y2809e/ y2809e00.htm Accesed 18 January 2018.

FAO/WHO (2004). Vitamin and mineral requirements in human nutrition. Eds: World Health Organization and Food and Agriculture Organization of the United Nations, 2nd edition. Sun Fung, China.

Ferguson, L. R., De Caterina, R., Görman, U., Allayee, H., Kohlmeier, M., Prasad, C., Choi, M. S., Curi, R., de Luis, D. A., Gil, Á., Kang, J. X., Martin, R. L., Milagro, F. I., Nicoletti, C. F., Nonino, C. B., Ordovas, J. M., Parslow, V. R., Portillo, M. P., Santos, J. L., Serhan, C. N., Simopoulos, A. P., Velázquez-Arellano, A., Zulet, M. A., \& Martinez, J. A. (2016). Guide and Position of the International Society of Nutrigenetics/Nutrigenomics on Personalised Nutrition: Part 1 - Fields of Precision Nutrition. Journal of Nutrigenetics and Nutrigenomics, 9(1), 12-27.

Finkelstein, J. L., Haas, J. D., \& Mehta, S. (2017). Iron-biofortified staple food crops for improving iron status: a review of the current evidence. Current Opinion in Biotechnology, 44, 138145.

Fisher, A. L., \& Nemeth, E. (2017). Iron homeostasis during pregnancy. American Journal of Clinical Nutrition, 106(Suppl 6), 1567S-1574S.

Fleming, R. E., Britton, R. S., Waheed, A., Sly, W. S., \& Bacon, B. R. (2005). Pathophysiology of hereditary hemochromatosis. Seminars in Liver Diseases, 25(4), 411-419.

Fonseca-Nunes, A., Jakszyn, P., \& Agudo, A. (2013). Iron and cancer risk-a systematic review and meta-analysis of the epidemiological evidence. Cancer Epidemiology and Prevention Biomarkers.

Ganz, T. (2013). Systemic iron homeostasis. Physiol Rev, 93(4), 1721-1741.

Ganz, T., \& Nemeth, E. (2012). Hepcidin and iron homeostasis. Biochimica et Biophysica Acta, 1823(9), 1434-1443.

Garrick, M. D., \& Garrick, L. M. (2009). Cellular iron transport. Biochimica et Biophysica Acta, 1790(5), 309-325.

Genevois, C. E., de Escalada Pla, M. F., \& Flores, S. K. (2016). Application of edible coatings to improve global quality of fortified pumpkin. Innovative Food Science \& Emerging Technologies, 33, 506-514. 
Gharibzahedi, S. M. T., \& Jafari, S. M. (2017a). Chapter 9 - Nanoencapsulation of Minerals. In Nanoencapsulation of Food Bioactive Ingredients, (pp. 333-400): Academic Press.

Gharibzahedi, S. M. T., \& Jafari, S. M. (2017b). The importance of minerals in human nutrition: Bioavailability, food fortification, processing effects and nanoencapsulation. Trends in Food Science \& Technology, 62, 119-132

Gordeuk, V. R., \& Brannon, P. M. (2017). Ethnic and genetic factors of iron status in women of reproductive age. American Journal of Clinical Nutrition, 106(Suppl 6), 1594S-1599S.

Gozzelino, R., \& Arosio, P. (2016). Iron Homeostasis in Health and Disease. International Journal of Molecular Sciences, 17(1), pii: E130.

Grantham-McGregor, S., \& Ani, C. (2001). A review of studies on the effect of iron deficiency on cognitive development in children. Journal of Nutrition, 131(2S-2), 649S-666S; discussion 688S-690S.

Greenwood, D. C., Cade, J. E., Moreton, J. A., O'Hara, B., Burley, V. J., Randerson-Moor, J. A., Kukalizch, K., Thompson, D., Worwood, M., \& Bishop, D. T. (2005). HFE genotype modifies the influence of heme iron intake on iron status. Epidemiology, 16(6), 802-805.

Haas, J. D., \& Brownlie, T. t. (2001). Iron deficiency and reduced work capacity: a critical review of the research to determine a causal relationship. Journal of Nutrition, 131(2S-2), 676S688S; discussion 688S-690S.

Hallberg, L., Björn-Rasmussen, E., Garby, L., Pleehachinda, R., \& Suwanik, R. (1978). Iron absorption from South-East Asian diets and the effect of iron fortification. American Journal of Clinical Nutrition, 31(8), 1403-1408.

Hallberg, L., Brune, M., \& Rossander, L. (1989). Iron absorption in man: ascorbic acid and dosedependent inhibition by phytate. American Journal of Clinical Nutrition, 49(1), 140-144.

Halterman, J. S., Kaczorowski, J. M., Aligne, C. A., Auinger, P., \& Szilagyi, P. G. (2001). Iron deficiency and cognitive achievement among school-aged children and adolescents in the United States. Pediatrics, 107(6), 1381-1386.

Han, O. (2011). Molecular mechanism of intestinal iron absorption. Metallomics, 3(2):103-109.

Hare, D. J., \& Double, K. L. (2016). Iron and dopamine: a toxic couple. Brain, 139(Pt 4), 1026-1035. Harvey, L. J., Armah, C. N., Dainty, J. R., Foxall, R. J., John Lewis, D., Langford, N. J., \& FairweatherTait, S. J. (2005). Impact of menstrual blood loss and diet on iron deficiency among women in the UK. British Journal of Nutrition, 94(4), 557-564. 
Hoppe, M., Hulthen, L., \& Hallberg, L. (2006). The relative bioavailability in humans of elemental iron powders for use in food fortification. European Journal of Nutrition, 45(1), 37-44.

Hoppe, M., Onning, G., Berggren, A., \& Hulthen, L. (2015). Probiotic strain Lactobacillus plantarum $299 \mathrm{v}$ increases iron absorption from an iron-supplemented fruit drink: a double-isotope cross-over single-blind study in women of reproductive age. British Journal of Nutrition, 114(8), 1195-1202.

Horton, S., \& Ross, J. (2003). The economics of iron deficiency. Food Policy, 28(1), 51-75.

Huh, E. C., Hotchkiss, A., Brouillette, J., \& Glahn, R. P. (2004). Carbohydrate fractions from cooked fish promote iron uptake by Caco-2 cells. Journal of Nutrition, 134(7), 1681-1689.

Huma, N., Salim-Ur-Rehman, Anjum, F. M., Murtaza, M. A., \& Sheikh, M. A. (2007). Food fortification strategy-preventing iron deficiency anemia: a review. Critical Reviews in Food Science and Nutrition, 47(3), 259-265.

Hunt, J. R., \& Zeng, H. (2004). Iron absorption by heterozygous carriers of the HFE C282Y mutation associated with hemochromatosis. American Journal of Clinical Nutrition, 80(4), 924-931.

Hunt, J. R., Zito, C. A., \& Johnson, L. K. (2009). Body iron excretion by healthy men and women. American Journal of Clinical Nutrition, 89(6), 1792-1798.

Hurrell, Lynch, Bothwell, Cori, Glahn, Hertrampf, Kratky, Rodenstein, Streekstra, \& Teucher. (2004). Enhancing the absorption of fortification iron: A SUSTAIN task force report. International Journal for Vitamin and Nutrition Research, 74(6), 387-401.

Hurrell, R. (2010). Use of ferrous fumarate to fortify foods for infants and young children. Nutrition Reviews, 68(9), 522-530.

Hurrell, R., \& Egli, I. (2010). Iron bioavailability and dietary reference values. The American Journal of Clinical Nutrition, 91(5), 1461S-1467S.

Hurrell, R. F., Reddy, M. B., Juillerat, M.-A., \& Cook, J. D. (2003). Degradation of phytic acid in cereal porridges improves iron absorption by human subjects. The American Journal of Clinical Nutrition, 77(5), 1213-1219.

Hurrell, R. F., Reddy, M. B., Juillerat, M., \& Cook, J. D. (2006). Meat protein fractions enhance nonheme iron absorption in humans. Journal Nutrition, 136(11), 2808-2812.

Hutchinson, C., Conway, R. E., Bomford, A., Hider, R. C., Powell, J. J., \& Geissler, C. A. (2008). Postprandial iron absorption in humans: comparison between HFE genotypes and iron deficiency anaemia. Clinical Nutrition, 27(2), 258-263. 
Institute of Medicine (2001). Dietary Reference Intakes for Vitamin A, Vitamin K, Arsenic, Boron, Chromium, Copper, lodine, Iron, Manganese, Molybdenum, Nickel, Silicon, Vanadium, and Zinc. Washington (DC): National Academies Press (US).

Institute of Medicine (2002). Iron tolerable upper intake levels. Nutr Clin Care, 5(5), 236-250. lyengar, V., Pullakhandam, R., \& Nair, K. M. (2010). Dietary ligands as determinants of iron-zinc interactions at the absorptive enterocyte. Journal of Food Science, 75(8).

Jaeggi, T., Kortman, G. A., Moretti, D., Chassard, C., Holding, P., Dostal, A., Boekhorst, J., Timmerman, H. M., Swinkels, D. W., Tjalsma, H., Njenga, J., Mwangi, A., Kvalsvig, J., Lacroix, C., \& Zimmermann, M. B. (2015). Iron fortification adversely affects the gut microbiome, increases pathogen abundance and induces intestinal inflammation in Kenyan infants. Gut, 64(5), 731-742.

Kaltwasser, J. P., Werner, E., Schalk, K., Hansen, C., Gottschalk, R., \& Seidl, C. (1998). Clinical trial on the effect of regular tea drinking on iron accumulation in genetic haemochromatosis. Gut, 43(5), 699-704.

Kapsokefalou, M., Alexandropoulou, I., Komaitis, M., \& Politis, I. (2005). In vitro evaluation of iron solubility and dialyzability of various iron fortificants and of iron-fortified milk products targeted for infants and toddlers. International Journal of Food Science and Nutrition, 56(4), 293-302.

Karn, S. K., Chavasit, V., Kongkachuichai, R., \& Tangsuphoom, N. (2011). Shelf stability, sensory qualities, and bioavailability of iron-fortified Nepalese curry powder. Food and Nutrition Bulletin, 32(1), 13-22.

Khan, M. K., Ahmad, K., Hassan, S., Imran, M., Ahmad, N., \& Xu, C. (2018). Effect of novel technologies on polyphenols during food processing. Innovative Food Science \& Emerging Technologies, 45, 361-381.

Kibangou, I. B., Bouhallab, S., Henry, G., Bureau, F., Allouche, S., Blais, A., Guérin, P., Arhan, P., \& Bouglé, D. L. (2005). Milk proteins and iron absorption: contrasting effects of different caseinophosphopeptides. Pediatric Research, 58(4), 731-734.

Kloots, W., Op den Kamp, D., \& Abrahamse, L. (2004). In vitro iron availability from iron-fortified whole-grain wheat flour. Journal of Agricultural and Food Chemistry, 52(26), 8132-8136.

Kordas, K., \& Stoltzfus, R. J. (2004). New evidence of iron and zinc interplay at the enterocyte and neural tissues. Journal of Nutrition, 134(6), 1295-1298. 
Laftah, A. H., Latunde-Dada, G. O., Fakih, S., Hider, R. C., Simpson, R. J., \& McKie, A. T. (2009). Haem and folate transport by proton-coupled folate transporter/haem carrier protein 1 (SLC46A1). British Journal of Nutrition, 101(8), 1150-1156.

Lall, R. K., Syed, D. N., Adhami, V. M., Khan, M. I., \& Mukhtar, H. (2015). Dietary polyphenols in prevention and treatment of prostate cancer. International Journal of Molecular Sciences, $16(2), 3350-3376$.

Lane, D. J. R., Merlot, A. M., Huang, M. L. H., Bae, D. H., Jansson, P. J., Sahni, S., Kalinowski, D. S., \& Richardson, D. R. (2015). Cellular iron uptake, trafficking and metabolism: Key molecules and mechanisms and their roles in disease. Biochimica et Biophysica Acta, 1853(5), 11301144.

Latunde-Dada, G., Van der Westhuizen, J., Vulpe, C., Anderson, G., Simpson, R., \& McKie, A. (2002). Molecular and functional roles of duodenal cytochrome B (Dcytb) in iron metabolism. Blood Cells, Molecules, and Diseases, 29(3), 356-360.

Latunde-Dada, G. O., Pereira, D. I., Tempest, B., Ilyas, H., Flynn, A. C., Aslam, M. F., Simpson, R. J., \& Powell, J. J. (2014). A nanoparticulate ferritin-core mimetic is well taken up by HuTu 80 duodenal cells and its absorption in mice is regulated by body iron. Journal of Nutrition, 144(12), 1896-1902.

Layrisse, M., Garcia-Casal, M. N., Solano, L., Baron, M. A., Arguello, F., Llovera, D., Ramirez, J., Leets, I., \& Tropper, E. (2000). Iron bioavailability in humans from breakfasts enriched with iron bis-glycine chelate, phytates and polyphenols. Journal of Nutrition, 130(9), 2195-2199.

Lee, K., Clydesdale, F. M., \& Tannenbaum, S. (1979). Iron sources used in food fortification and their changes due to food processing. Critical Reviews in Food Science \& Nutrition, 11(2), 117-153.

Lombardi-Boccia, G., Martinez-Dominguez, B., \& Aguzzi, A. (2002). Total Heme and Non-heme Iron in Raw and Cooked Meats. Journal of Food Science, 67(5), 1738-1741.

Lukaski, H. C., Bolonchuk, W. W., Klevay, L. M., Milne, D. B., \& Sandstead, H. H. (2001). Interactions among dietary fat, mineral status, and performance of endurance athletes: a case study. International Journal of Sport Nutrition and Exercise Metabolism, 11(2), 186-198.

Lynch, S. R., \& Stoltzfus, R. J. (2003). Iron and ascorbic acid: proposed fortification levels and recommended iron compounds. Journal of Nutrition, 133(9), 2978S-2984S. 
Mahler, G. J., Esch, M. B., Tako, E., Southard, T. L., Archer, S. D., Glahn, R. P., \& Shuler, M. L. (2012). Oral exposure to polystyrene nanoparticles affects iron absorption. Nature Nanotechnol, 7(4), 264-271.

Martinsson, A., Andersson, C., Andell, P., Koul, S., Engström, G., \& Smith, J. G. (2014). Anemia in the general population: prevalence, clinical correlates and prognostic impact. European Journal of Epidemiology, 29(7), 489-498.

McCann, J. C., \& Ames, B. N. (2007). An overview of evidence for a causal relation between iron deficiency during development and deficits in cognitive or behavioral function. American Journal of Clinical Nutrition, 85(4), 931-945.

McMahon, L. P. (2010). Iron deficiency in pregnancy. Obstetric Medicine, 3(1), 17-24.

Mejia, E. G., Aguilera-Gutiérrez, Y., Martin-Cabrejas, M. A., \& Mejia, L. A. (2015). Industrial processing of condiments and seasonings and its implications for micronutrient fortification. Annals of the New York Academy of Sciences, 1357(1), 8-28.

Merryweather-Clarke, A. T., Pointon, J. J., Jouanolle, A. M., Rochette, J., \& Robson, K. J. (2000). Geography of HFE C282Y and H63D mutations. Genetic Testing, 4(2), 183-198.

Mesías, M., Seiquer, I., \& Navarro, M. P. (2013). Iron nutrition in adolescence. Critical Reviews in Food Science and Nutrition, 53(11), 1226-1237.

Milward, E. A., Baines, S. K., Knuiman, M. W., Bartholomew, H. C., Divitini, M. L., Ravine, D. G., Bruce, D. G., \& Olynyk, J. K. (2008). Noncitrus fruits as novel dietary environmental modifiers of iron stores in people with or without HFE gene mutations. Mayo Clinic Proceedings, 83(5), 543-549.

Miret, S., Saiz, M., \& Mitjavila, M. (2003). Effects of fish oil-and olive oil-rich diets on iron metabolism and oxidative stress in the rat. British Journal of Nutrition, 89(1), 11-18.

Monsen, E. R., Hallberg, L., Layrisse, M., Hegsted, D. M., Cook, J. D., Mertz, W., \& Finch, C. A. (1978). Estimation of available dietary iron. American Journal of Clinical Nutrition, 31(1), 134-141.

Moreiras, O., Carbajal, A., Cabrera, L., \& Cuadrado, C. (2016). Ingestas recomendadas de energía y nutrientes para la población española (Revisadas 2015). Departamento de Nutrición. Universidad Complutense de Madrid (pp. 227-230). Tablas de composición de alimentos. Ediciones Pirámide (Grupo Anaya, SA). 18a edición revisada y ampliada. 
Moyano, G., Sáyago-Ayerdi, S. G., Largo, C., Caz, V., Santamaria, M., \& Tabernero, M. (2016). Potential use of dietary fibre from Hibiscus sabdariffa and Agave tequilana in obesity management. Journal of Functional Foods, 21, 1-9.

Musallam, K. M., Tamim, H. M., Richards, T., Spahn, D. R., Rosendaal, F. R., Habbal, A., Khreiss, M., Dahdaleh, F. S., Khavandi, K., Sfeir, P. M., Soweid, A., Hoballah, J. J., Taher, A. T., \& Jamali, F. R. (2011). Preoperative anaemia and postoperative outcomes in non-cardiac surgery: a retrospective cohort study. Lancet, 378(9800), 1396-1407.

Navas-Carretero, S., Pérez-Granados, A. M., Sarriá, B., Carbajal, A., Pedrosa, M. M., Roe, M. A., Fairweather-Tait, S. J., \& Vaquero, M. P. (2008). Oily fish increases iron bioavailability of a phytate rich meal in young iron deficient women. Journal of the American College of Nutrition, 27(1), 96-101.

Navas-Carretero, S., Pérez-Granados, A. M., Sarriá, B., Schoppen, S., \& Vaquero, M. P. (2007a). Iron Bioavailability from Pate Enriched with Encapsulated Ferric Pyrophosphate or Ferrous Gluconate in Rats. Food Science and Technology International, 13(2), 159-163.

Navas-Carretero, S., Pérez-Granados, A. M., Sarriá, B., \& Vaquero, M. P. (2009). Iron absorption from meat pate fortified with ferric pyrophosphate in iron-deficient women. Nutrition, 25(1), 20-24.

Navas-Carretero, S., Sarria, B., Pérez-Granados, A., Schoppen, S., Izquierdo-Pulido, M., \& Vaquero, M. (2007b). A comparative study of iron bioavailability from cocoa supplemented with ferric pyrophosphate or ferrous fumarate in rats. Annals of Nutrition and Metabolism, 51(3), 204-207.

Nemeth, E., Tuttle, M. S., Powelson, J., Vaughn, M. B., Donovan, A., Ward, D. M., Ganz, T., \& Kaplan, J. (2004). Hepcidin regulates cellular iron efflux by binding to ferroportin and inducing its internalization. Science, 306(5704), 2090-2093.

Nielsen, A. V., Tetens, I., \& Meyer, A. S. (2013). Potential of phytase-mediated iron release from cereal-based foods: a quantitative view. Nutrients, 5(8), 3074-3098.

Nordic Council of Ministers (2014). Nordic nutrition recommendations 2012: integrating nutrition and physical activity: Nordic Council of Ministers.

Ordovas, J. M., \& Corella, D. (2004). Nutritional genomics. Annu Rev Genomics Hum Genet, 5, 71118.

Paganini, D., Uyoga, M. A., Kortman, G. A. M., Cercamondi, C. I., Moretti, D., Barth-Jaeggi, T., Schwab, C., Boekhorst, J., Timmerman, H. M., Lacroix, C., Karanja, S., \& Zimmermann, M. 
B. (2017). Prebiotic galacto-oligosaccharides mitigate the adverse effects of iron fortification on the gut microbiome: a randomised controlled study in Kenyan infants. Gut, 66(11), 1956-1967.

Paganini, D., \& Zimmermann, M. B. (2017). The effects of iron fortification and supplementation on the gut microbiome and diarrhea in infants and children: a review. American Journal of Clinical Nutrition, 106(Suppl 6), 1688s-1693s.

Pasricha, S. R., \& Drakesmith, H. (2016). Iron Deficiency Anemia: Problems in Diagnosis and Prevention at the Population Level. Hematology/Oncology Clinics of North America, 30(2), 309-325.

Paul, V. D., \& Lill, R. (2015). Biogenesis of cytosolic and nuclear iron-sulfur proteins and their role in genome stability. Biochimica et Biophysica Acta, 1853(6), 1528-1539.

Pereira, D. I., Bruggraber, S. F., Faria, N., Poots, L. K., Tagmount, M. A., Aslam, M. F., Frazer, D. M., Vulpe, C. D., Anderson, G. J., \& Powell, J. J. (2014). Nanoparticulate iron(III) oxo-hydroxide delivers safe iron that is well absorbed and utilised in humans. Nanomedicine, 10(8), 18771886.

Pérès, J.-M., Bouhallab, S., Petit, C., Bureau, F., Maubois, J.-L., Arhan, P., \& Bouglé, D. (1998). Improvement of zinc intestinal absorption and reduction of zinc/iron interaction using metal bound to the caseinophosphopeptide 1-25 of $\beta$-casein. Reproduction Nutrition \& Development, 38(4), 465-472.

Pérez-Granados, A. M., Vaquero, M. P., \& Navarro, M. P. (1995). Iron metabolism in rats consuming oil from fresh or fried sardines. Analyst, 120(3), 899-903.

Petry, N., Boy, E., Wirth, J. P., \& Hurrell, R. F. (2015). Review: The potential of the common bean (Phaseolus vulgaris) as a vehicle for iron biofortification. Nutrients, 7(2), 1144-1173.

Prentice, A. M., Mendoza, Y. A., Pereira, D., Cerami, C., Wegmuller, R., Constable, A., \& Spieldenner, J. (2017). Dietary strategies for improving iron status: balancing safety and efficacy. Nutrition Reviews, 75(1), 49-60.

Ramzani, P. M. A., Khalid, M., Naveed, M., Ahmad, R., \& Shahid, M. (2016). Iron biofortification of wheat grains through integrated use of organic and chemical fertilizers in $\mathrm{pH}$ affected calcareous soil. Plant Physiology and Biochemistry, 104, 284-293.

Rasmussen, K. (2001). Is There a Causal Relationship between Iron Deficiency or Iron-Deficiency Anemia and Weight at Birth, Length of Gestation and Perinatal Mortality? Journal of Nutrition, 131(2S-2), 590S-601S; discussion 601S-603S. 
Remacha, A. (2011). El déficit de hierro. In: Fundación Tomás Pascual \& Pilar Gómez-Cuétara, COFM \& RANF (Eds), Interrogantes y educación sanitaria para la Oficina de Farmacia (pp. 123-138) Madrid, Spain.

Roe, M. A., Heath, A. L., Oyston, S. L., Macrow, C., Hoogewerff, J. A., Foxall, R., Dainty, J. R., Majsak-Newman, G., Willis, G., \& Fairweather-Tait, S. J. (2005). Iron absorption in male C282Y heterozygotes. American Journal of Clinical Nutrition, 81(4), 814-821.

Rybinska, I., \& Cairo, G. (2017). Mutual Cross Talk Between Iron Homeostasis and Erythropoiesis. Vitamins and Hormones, 105, 143-160.

Sarriá, B., Navas-Carretero, S., López-Parra, A. M., Pérez-Granados, A. M., Arroyo-Pardo, E., Roe, M. A., Teucher, B., Vaquero, M. P., \& Fairweather-Tait, S. J. (2007). The G277S transferrin mutation does not affect iron absorption in iron deficient women. European Journal of Nutrition, 46(1), 57-60.

Schlingmann, K. P., Kaufmann, M., Weber, S., Irwin, A., Goos, C., John, U., Misselwitz, J., Klaus, G., Kuwertz-Bröking, E., Fehrenbach, H., Wingen, A. M., Güran, T., Hoenderop, J. G., Bindels, R. J., Prosser, D. E., Jones, G., \& Konrad, M. (2011). Mutations in CYP24A1 and Idiopathic Infantile Hypercalcemia. New England Journal of Medicine, 365(5), 410-421.

Scholl, T. O. (2011). Maternal iron status: relation to fetal growth, length of gestation, and iron endowment of the neonate. Nutrition Reviews, 69 Suppl 1, S23-29.

Scotet, V., Mérour, M. C., Mercier, A. Y., Chanu, B., Le Faou, T., Raguénes, O., Le Gac, G., Mura, C., Nousbaum, J. B., \& Férec, C. (2003). Hereditary hemochromatosis: effect of excessive alcohol consumption on disease expression in patients homozygous for the $\mathrm{C} 282 \mathrm{Y}$ mutation. American Journal of Epidemiology, 158(2), 129-134.

Shamah-Levy, T., Villalpando, S., Rivera-Dommarco, J. A., Mundo-Rosas, V., Cuevas-Nasu, L., \& Jimenez-Aguilar, A. (2008). Ferrous gluconate and ferrous sulfate added to a complementary food distributed by the Mexican nutrition program Oportunidades have a comparable efficacy to reduce iron deficiency in toddlers. Journal of Pediatric Gastroenterology and Nutrition, 47(5), 660-666.

Sharp, P. A. (2010). Intestinal iron absorption: regulation by dietary \& systemic factors. International Journal for Vitamins and Nutrition Research, 80(4-5), 231-242.

Sharp, P., \& Srai, S.K. (2007). Molecular mechanisms involved in intestinal iron absorption. World Journal of Gastroenterology, 13(35):4716-4724 
Shayeghi, M., Latunde-Dada, G. O., Oakhill, J. S., Laftah, A. H., Takeuchi, K., Halliday, N., Khan, Y., Warley, A., McCann, F. E., Hider, R. C., Frazer, D. M., Anderson, G. J., Vulpe, C. D., Simpson, R. J., \& McKie, A. T. (2005). Identification of an Intestinal Heme Transporter. Cell, 122(5), 789-801.

Shilpashree, B.G., Arora, S., Sharma, V., \& Singh, A.K. (2015). Preparation of succinylated sodium caseinate-iron complex by adopting ultrafiltration technology: a novel food fortificant. Innovative Food Science \& Emerging Technologies, 32, 165-171.

Siegenberg, D., Baynes, R. D., Bothwell, T. H., Macfarlane, B. J., Lamparelli, R. D., Car, N., MacPhail, P., Schmidt, U., Tal, A., \& Mayet, F. (1991). Ascorbic acid prevents the dose-dependent inhibitory effects of polyphenols and phytates on nonheme-iron absorption. American Journal of Clinical Nutrition, 53(2), 537-541.

Silva, B., \& Faustino, P. (2015). An overview of molecular basis of iron metabolism regulation and the associated pathologies. Biochimica et Biophysica Acta, 1852(7), 1347-1359.

Simovich, M., Hainsworth, L. N., Fields, P. A., Umbreit, J. N., \& Conrad, M. E. (2003). Localization of the iron transport proteins Mobilferrin and DMT-1 in the duodenum: the surprising role of mucin. American Journal of Hematology, 74(1), 32-45.

Skikne, B., \& Hershko, C. (2012). Iron Deficiency. In G. J. Anderson \& G. D. McLaren (Eds.), Iron Physiology and Pathophysiology in Humans (pp. 251-282). Totowa, NJ: Humana Press.

Span, K., Verhoef, J. J., Hunt, H., van Nostrum, C. F., Brinks, V., Schellekens, H., \& Hennink, W. E. (2016). A novel oral iron-complex formulation: Encapsulation of hemin in polymeric micelles and its in vitro absorption. European Journal of Pharmaceutics and Biopharmaceutics, 108, 226-234.

Staroń, R., Lipiński, P., Lenartowicz, M., Bednarz, A., Gajowiak, A., Smuda, E., Krzeptowski, W., Pieszka, M., Korolonek, T., Hamza, I., Swinkels, D. W., Van Swelm, R. P. L., \& Starzyński, R. R. (2017). Dietary hemoglobin rescues young piglets from severe iron deficiency anemia: Duodenal expression profile of genes involved in heme iron absorption. PLoS One, 12(7), e0181117.

Stevens, G. A., Finucane, M. M., De-Regil, L. M., Paciorek, C. J., Flaxman, S. R., Branca, F., PenaRosas, J. P., Bhutta, Z. A., Ezzati, M., \& Nutrition Impact Model Study, G. (2013). Global, regional, and national trends in haemoglobin concentration and prevalence of total and severe anaemia in children and pregnant and non-pregnant women for 1995-2011: a systematic analysis of population-representative data. Lancet Global Health, 1(1), e16-25. 
Szymlek-Gay, E. A., Lönnerdal, B., Abrams, S. A., Kvistgaard, A. S., Domellöf, M., \& Hernell, O. (2012). $\alpha$-Lactalbumin and casein-glycomacropeptide do not affect iron absorption from formula in healthy term infants. Journal of Nutrition, 142(7), 1226-1231.

Tangney, C. C., \& Rasmussen, H. E. (2013). Polyphenols, inflammation, and cardiovascular disease. Current Atherosclerosis Reports, 15(5), 324.

Teucher, Olivares, \& Cori. (2004). Enhancers of iron absorption: ascorbic acid and other organic acids. International Journal for Vitamin and Nutrition Research, 74(6), 403-419.

Theil, E. C. (2013). Ferritin: the protein nanocage and iron biomineral in health and in disease. Inorganic Chemistry, 52(21), 12223-12233.

Theil, E. C., Chen, H., Miranda, C., Janser, H., Elsenhans, B., Nunez, M. T., Pizarro, F., \& Schumann, K. (2012). Absorption of iron from ferritin is independent of heme iron and ferrous salts in women and rat intestinal segments. Journal of Nutrition, 142(3), 478-483.

Thein, M., Ershler, W. B., Artz, A. S., Tecson, J., Robinson, B. E., Rothstein, G., Liede, A., GylysColwell, I., Lu, Z. J., \& Robbins, S. (2009). Diminished quality of life and physical function in community-dwelling elderly with anemia. Medicine (Baltimore), 88(2), 107-114.

Toxqui, L., De Piero, A., Courtois, V., Bastida, S., Sánchez-Muniz, F. J., \& Vaquero, M. P. (2010). [Iron deficiency and overload. Implications in oxidative stress and cardiovascular health]. Nutrición Hospitalaria, 25(3), 350-365.

Toxqui, L., Pérez-Granados, A. M., Blanco-Rojo, R., Wright, I., González-Vizcayno, C., \& Vaquero, M. P. (2013). Effects of an iron or iron and vitamin D-fortified flavored skim milk on iron metabolism: a randomized controlled double-blind trial in iron-deficient women. Journal of the American College of Nutrition, 32(5), 312-320.

Toxqui, L., Pérez-Granados, A. M., Blanco-Rojo, R., Wright, I., de la Piedra, C., \& Vaquero, M. P. (2014a). Low iron status as a factor of increased bone resorption and effects of an iron and vitamin D-fortified skimmed milk on bone remodelling in young Spanish women. European Journal of Nutrition, 53(2), 441-448.

Toxqui, L., Pérez-Granados, A. M., Blanco-Rojo, R., Wright, I., \& Vaquero, M. P. (2014b). A simple and feasible questionnaire to estimate menstrual blood loss: relationship with hematological and gynecological parameters in young women. BMC Womens Health, 14, 71.

Toxqui, L., \& Vaquero, M. P. (2015). Chronic iron deficiency as an emerging risk factor for osteoporosis: a hypothesis. Nutrients, 7(4), 2324-2344. 
Turner, N. D., \& Lloyd, S. K. (2017). Association between red meat consumption and colon cancer: A systematic review of experimental results. Experimental Biology and Medicine (Maywood), 242(8), 813-839.

Van Dokkum, W. (2003). The concept of mineral bioavailability. In: M.P. Vaquero, T. García-Arias, \& A. Carbajal (Eds.), Bioavailability of micronutrients and minor dietary compounds. Metabolic and Technological aspects (pp. 1-18). Trivandrum, India: Research Signpost. Vaquero, M. P. (2011). La nutrición en la prevención de la deficiencia de hierro. Interrogantes y educación sanitaria para la Oficina de Farmacia. Eds Fundación Tomás Pascual y Pilar Gómez-Cuétara, COFM y RANF. Madrid, Spain, 139-146.

Vaquero, M. P. (1992). In vitro availability of calcium, magnesium, iron, copper and zinc from white or brown bread separately or in combination with other foods. Revista Española de Ciencia y Tecnología de Alimentos, 32(1), 47-58.

Vaquero, M. P., García-Quismondo, Á., Cañizo, F. J. d., \& Sánchez-Muniz, F. J. (2017). Iron Status Biomarkers and Cardiovascular Risk. In A. Kumar (Ed.), Recent Trends in Cardiovascular Risks (pp. Ch. 06). Rijeka: InTech.

Vaquero, M. P., Veldhuizen, M., \& Sarriá, B. (2001). Consumption of an infant formulas supplemented with long-chain polyunsaturated fatty acids and iron metabolism in rats. Innovative Food Science \& Emerging Technologies, 2: 2011-2017.

Vasta, J. D., Higgin, J. J., Kersteen, E. A., \& Raines, R. T. (2013). Bioavailable affinity label for collagen prolyl 4-hydroxylase. Bioorganic \& Medicinal Chemistry, 21(12), 3597-3601.

Vasta, J. D., \& Raines, R. T. (2016). Human Collagen Prolyl 4-Hydroxylase Is Activated by Ligands for Its Iron Center. Biochemistry, 55(23), 3224-3233.

Villalpando, S., Shamah, T., Rivera, J. A., Lara, Y., \& Monterrubio, E. (2006). Fortifying milk with ferrous gluconate and zinc oxide in a public nutrition program reduced the prevalence of anemia in toddlers. Journal of Nutrition, 136(10), 2633-2637.

Vricella, L. K. (2017). Emerging understanding and measurement of plasma volume expansion in pregnancy. American Journal of Clinical Nutrition, 106(Suppl 6):1620S-1625S.

Walczyk, T., Muthayya, S., Wegmüller, R., Thankachan, P., Sierksma, A., Frenken, L. G., Thomas, T., Kurpad, A., \& Hurrell, R. F. (2014). Inhibition of iron absorption by calcium is modest in an iron-fortified, casein-and whey-based drink in Indian children and is easily compensated for by addition of ascorbic acid. Journal of Nutrition, 144(11), 1703-1709. 
Wegmuller, R., Zimmermann, M. B., Moretti, D., Arnold, M., Langhans, W., \& Hurrell, R. F. (2004). Particle size reduction and encapsulation affect the bioavailability of ferric pyrophosphate in rats. Journal of Nutrition, 134(12), 3301-3304.

World Health Organization (2006). Guidelines on food fortification with micronutrients. Geneva, Switzerland: WHO and FAO.

World Health Organization. (2012). Global targets 2025. To improve maternal, infant and young child nutrition In (Vol. 2017).

World Health Organization. (2014). Global nutrition targets 2025: anaemia policy brief. In (Vol. 2017). Geneva.

World Health Organization. (2015). The global prevalence of anaemia in 2011. Geneva.

Wright, I., Blanco-Rojo, R., Fernández, M. C., Toxqui, L., Moreno, G., Pérez-Granados, A. M., de la Piedra, C., Remacha, A. F., \& Vaquero, M. P. (2013). Bone remodelling is reduced by recovery from iron-deficiency anaemia in premenopausal women. Journal of Physiology and Biochemistry, 69(4), 889-896.

Ye, K., Cao, C., Lin, X., O’Brien, K. O., \& Gu, Z. (2015). Natural selection on HFE in Asian populations contributes to enhanced non-heme iron absorption. BMC Genetics, 16, 61. 
Figure 1. Mechanisms of iron absorption in duodenal enterocytes. Continuous thick arrows indicate main mechanisms; dashed arrows indicate minor routes or doubts about the mechanism. Dcytb, duodenal cytochrome b reductase; DMT-1, divalent metal transporter-1; FPN, ferroportin; HCP-1, haem-carrier protein; Flavin-MO, flavin monooxygenase; $\beta 2$-m; $\beta 2$-microglobulin; HO, haem oxygenase.

Figure 2. Host and environmental factors, including dietary factors, modulating iron bioavailability.

Figure 3. Strategies to improve iron bioavailability of fortified food. 
Table 1. Global and United Nations regional mean blood haemoglobin concentration and prevalence of anaemia by population group for 2011 (World Health Organization, 2015).

\begin{tabular}{|c|c|c|c|c|}
\hline \multirow[b]{2}{*}{$\begin{array}{l}\text { United } \\
\text { Nations } \\
\text { region }\end{array}$} & \multicolumn{2}{|c|}{ Children aged 6-59 months } & \multicolumn{2}{|c|}{$\begin{array}{l}\text { All women of reproductive age (15-49 } \\
\text { years) }\end{array}$} \\
\hline & $\begin{array}{l}\text { Mean }(95 \% \mathrm{Cl}) \\
\text { blood } \\
\text { haemoglobin } \\
\text { concentration } \\
\quad(\mathrm{g} / \mathrm{L})\end{array}$ & $\begin{array}{l}\text { Percentage ( } 95 \% \\
\mathrm{Cl} \text { ) of population } \\
\text { with anaemia }\end{array}$ & $\begin{array}{l}\text { Mean }(95 \% \mathrm{Cl}) \text { blood } \\
\text { haemoglobin } \\
\text { concentration }(\mathrm{g} / \mathrm{L})\end{array}$ & $\begin{array}{l}\text { Percentage (95\% } \\
\mathrm{Cl} \text { ) of population } \\
\text { with anaemia }\end{array}$ \\
\hline Africa & 105 (103 to 106$)$ & $\begin{array}{c}60.2(57.0 \text { to } \\
63.1)\end{array}$ & $123(121$ to 125$)$ & $\begin{array}{c}37.6(32.4 \text { to } \\
43.0)\end{array}$ \\
\hline $\begin{array}{l}\text { Latin America } \\
\text { and the } \\
\text { Caribbean }\end{array}$ & 117 (114 to 120$)$ & $\begin{array}{c}29.1(22.5 \\
36.9)\end{array}$ & 130 (126 to 134$)$ & $\begin{array}{c}19.1(13.1 \text { to } \\
29.4)\end{array}$ \\
\hline $\begin{array}{l}\text { Northern } \\
\text { America }\end{array}$ & 124 (122 to125) & 7.0 (4.9 to 12.3 ) & 131 (130 to 133 ) & 12.4 (9.3 to 17.1$)$ \\
\hline Asia & 112 (109 to 115 ) & $\begin{array}{c}42.0(34.1 \text { to } \\
49.9)\end{array}$ & 124 (122 to 127$)$ & $\begin{array}{c}31.9(24.6 \text { to } \\
40.6)\end{array}$ \\
\hline Europe & $120(116 t$ & $\begin{array}{c}19.3(10.9 \text { to } \\
30.7)\end{array}$ & 129 (126 to 131$)$ & $\begin{array}{c}20.1(13.8 \text { to } \\
28.3)\end{array}$ \\
\hline Oceania & 117 (112 to 122$)$ & $\begin{array}{c}26.2(14.5 \text { to } \\
41.6)\end{array}$ & 128 (123 to 132$)$ & $\begin{array}{l}20.0(12.0 \text { to } \\
35.5)\end{array}$ \\
\hline Global & $111(110$ to 113$)$ & $\begin{array}{c}42.6(37.7 \text { to } \\
47.4)\end{array}$ & 125 (124 to 127$)$ & $\begin{array}{c}29.4(24.5 \text { to } \\
35.0)\end{array}$ \\
\hline
\end{tabular}


Table 2. Main enhancers and inhibitors of iron bioavailability.
Food or food
Components
Mechanism
Notes
References

group

\begin{tabular}{|c|c|c|c|c|c|}
\hline \multirow[t]{2}{*}{ Enhancers } & $\begin{array}{l}\text { Citric fruits, } \\
\text { vegetables, } \\
\text { citrus fruit juices }\end{array}$ & Ascorbic acid & $\begin{array}{l}\text { Formation of soluble iron- } \\
\text { ascorbate complexes which } \\
\text { remain soluble in the } \\
\text { intestine; and reduction of } \\
\mathrm{Fe}^{3+} \text { to } \mathrm{Fe}^{2+} \text {. Both favour } \\
\text { absorption }\end{array}$ & $\begin{array}{l}\text { Ascorbic acid is the most } \\
\text { potent enhancer. But it is } \\
\text { thermolabile }\end{array}$ & $\begin{array}{l}\text { (Beck et al., 2011; Blanco- } \\
\text { Rojo et al., 2011b; Hurrell, } \\
\text { Reddy, Juillerat, \& Cook, } \\
\text { 2003) }\end{array}$ \\
\hline & $\begin{array}{l}\text { Meat, fish, } \\
\text { poultry }\end{array}$ & Animal tissue & $\begin{array}{l}\text { Binding of iron to digestion } \\
\text { products mainly from } \\
\text { proteins resulting in soluble } \\
\text { complexes }\end{array}$ & $\begin{array}{l}\text { Not affected by thermal } \\
\text { processes }\end{array}$ & $\begin{array}{l}\text { (Bæch et al., 2003b; } \\
\text { Hurrell, Reddy, Juillerat, \& } \\
\text { Cook, 2006; Navas- } \\
\text { Carretero et al., 2008; } \\
\text { Navas-Carretero et al., } \\
\text { 2009) }\end{array}$ \\
\hline Inhibitors & $\begin{array}{l}\text { Coffee, tea, } \\
\text { cocoa }\end{array}$ & Polyphenols & $\begin{array}{l}\text { Formation of insoluble } \\
\text { complexes with iron in the } \\
\text { gut }\end{array}$ & $\begin{array}{l}\text { Polyphenols in tea are the } \\
\text { strongest known inhibitors }\end{array}$ & $\begin{array}{l}\text { (Navas-Carretero et al., } \\
\text { 2007b) }\end{array}$ \\
\hline
\end{tabular}




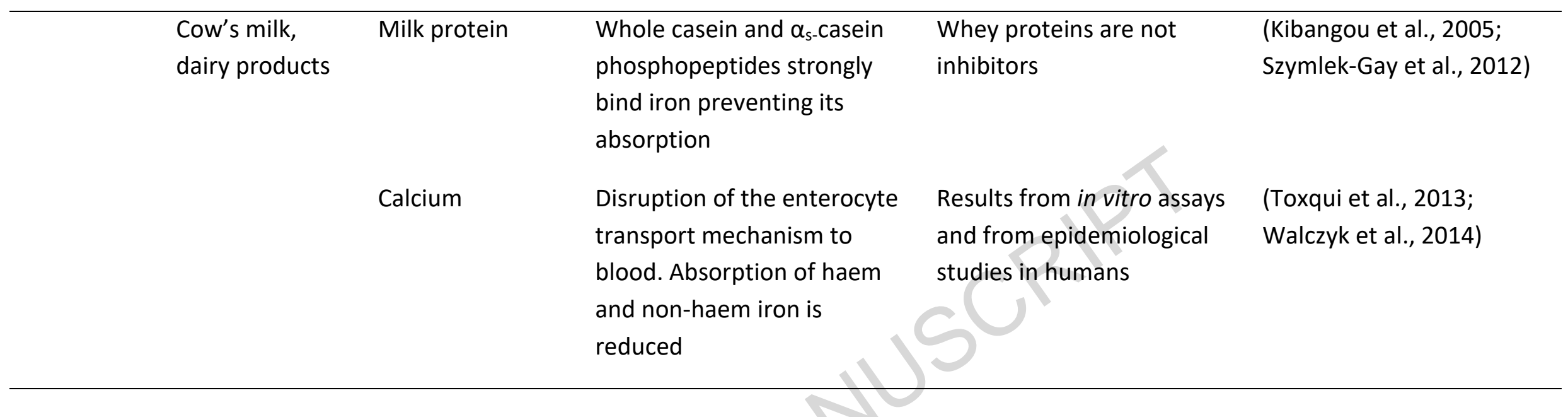


Table 3. Recommended Dietary Intake of iron ( $\mathrm{mg} /$ day) by age and gender among different agencies and countries selected.

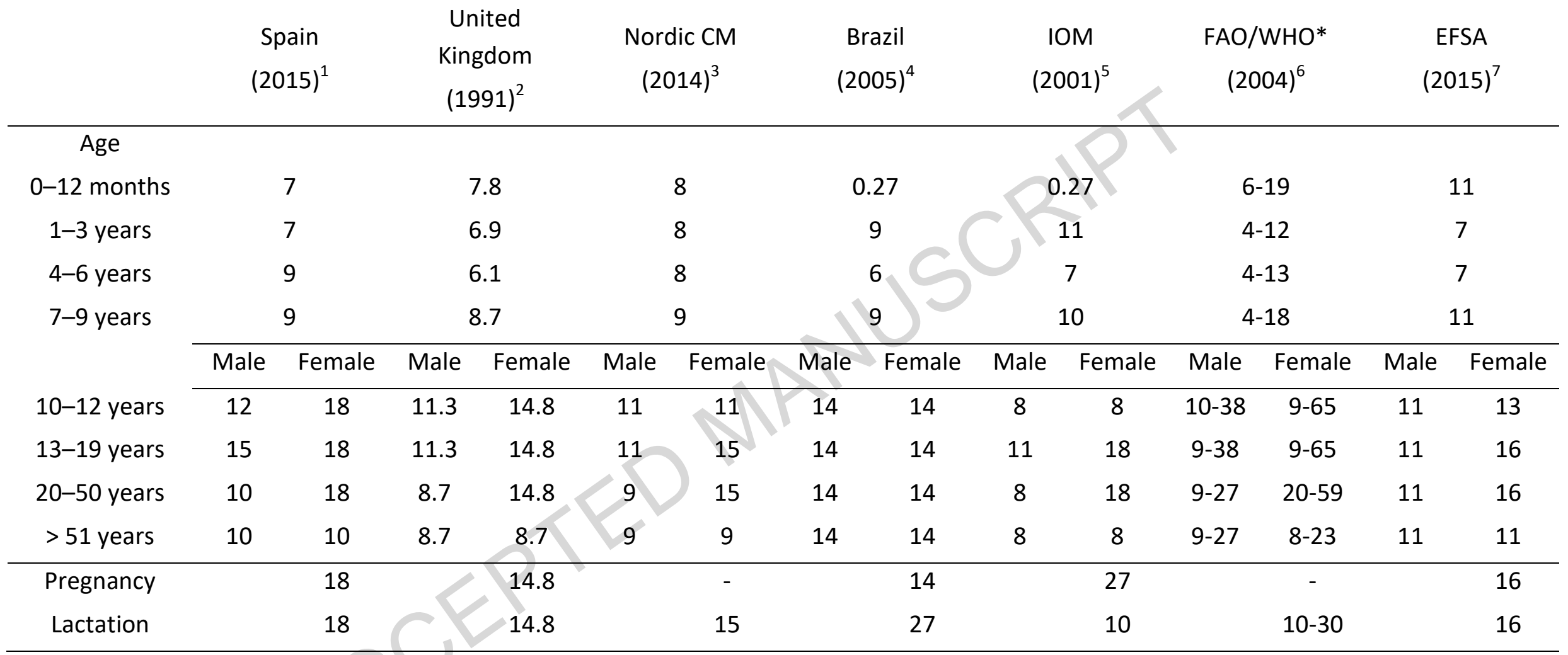

* Recommended Nutrient Intake for a bioavailability of dietary iron between 5 and $15 \%$.

${ }^{1}$ Moreiras, Carbajal, Cabrera, \& Cuadrado, 2016; ${ }^{2}$ Department of Health UK, 1991; ${ }^{3}$ Nordic Council of Ministers, 2014; ${ }^{4}$ Brasil, 2005;

${ }^{5}$ Institute of Medicine, 2001; ${ }^{6}$ FAO/WHO, 2004; ${ }^{7}$ European Food Safety Authority, 2015. 
Table 4. Characteristics of iron fortificants.

\begin{tabular}{|c|c|c|c|c|c|}
\hline Compound & $\begin{array}{c}\mathrm{Fe} \\
\text { content } \\
(\%)\end{array}$ & Solubility & $\begin{array}{c}\text { Relative } \\
\text { bioavailability* }\end{array}$ & $\begin{array}{l}\text { Main food } \\
\text { vehicles }\end{array}$ & Selected references \\
\hline \multicolumn{6}{|l|}{$\begin{array}{l}\text { Traditional } \\
\text { compounds }\end{array}$} \\
\hline Ferrous sulfate. $7 \mathrm{H}_{2} \mathrm{O}$ & 20 & Water soluble & 100 & $\begin{array}{l}\text { Infant foods, dry } \\
\text { milk, cereals }\end{array}$ & $\begin{array}{l}\text { (Shamah-Levy et al., 2008; Villalpando et al., } \\
\text { 2006) }\end{array}$ \\
\hline Ferrous gluconate & 12 & Water soluble & $85-95$ & Cereals, fruit juice & $\begin{array}{l}\text { (Navas-Carretero et al., 2007b; Shamah-Levy } \\
\text { et al., 2008; Villalpando et al., 2006) }\end{array}$ \\
\hline Ferrous lactate & 19 & Water soluble & 106 & $\begin{array}{l}\text { Cereals, dairy } \\
\text { products }\end{array}$ & $\begin{array}{l}\text { (Kapsokefalou, Alexandropoulou, Komaitis, \& } \\
\text { Politis, 2005; Kloots, Op den Kamp, \& } \\
\text { Abrahamse, 2004) }\end{array}$ \\
\hline Ferrous bisglycinate & 20 & Water soluble & $>100$ & Cereals, fluid milk & (Layrisse et al., 2000) \\
\hline $\begin{array}{l}\text { Ferric ammonium } \\
\text { citrate }\end{array}$ & 17 & Water soluble & 51 & Cereals, fluid milk & (Diego Quintaes, Barberá, \& Cilla, 2017) \\
\hline Sodium iron EDTA & 13 & Water solu & $>100$ & $\begin{array}{l}\text { Cereals, sugar, } \\
\text { fish sauce, soy } \\
\text { sauce }\end{array}$ & (European Food Safety Authority, 2010) \\
\hline Iron (II) taurate & 18 & Water soluble & - & Soft drinks & (European Food Safety Authority, 2009) \\
\hline Iron L-pidolate & 18 & Water soluble & - & - & (European Food Safety Authority, 2007) \\
\hline Ferrous fumarate & 33 & $\begin{array}{l}\text { Poorly water } \\
\text { soluble, soluble in } \\
\text { dilute acid }\end{array}$ & 100 & $\begin{array}{l}\text { Cereals, cocoa } \\
\text { products }\end{array}$ & $\begin{array}{l}\text { (Davidsson et al., 2000; Hurrell, 2010; Navas- } \\
\text { Carretero et al., 2007b) }\end{array}$ \\
\hline Ferric pyrophosphate & 25 & $\begin{array}{l}\text { Water insoluble, } \\
\text { poorly soluble in } \\
\text { dilute acid }\end{array}$ & $21-74$ & Cereals, fluid milk & (Wegmuller et al., 2004) \\
\hline $\begin{array}{l}\text { Elemental electrolytic } \\
\text { iron }\end{array}$ & $97-99$ & $\begin{array}{l}\text { Water insoluble, } \\
\text { poorly soluble in } \\
\text { dilute acid }\end{array}$ & 75 & $\begin{array}{l}\text { Cereals, breakfast } \\
\text { cereals, curry } \\
\text { powder }\end{array}$ & $\begin{array}{l}\text { (Hoppe, Hulthen, \& Hallberg, 2006; Karn et } \\
\text { al., 2011) }\end{array}$ \\
\hline
\end{tabular}




\begin{tabular}{|c|c|c|c|c|}
\hline \multicolumn{5}{|l|}{ Encapsulated iron } \\
\hline Ferrous sulfate & $\begin{array}{l}\text { Coating } \\
\text { dependent }\end{array}$ & 100 & $\begin{array}{l}\text { Cereals, cocoa } \\
\text { products, salt }\end{array}$ & (Genevois et al., 2016) \\
\hline Ferrous fumarate & $\begin{array}{l}\text { Coating } \\
\text { dependent }\end{array}$ & 100 & Cereals, salt & (Diego Quintaes, Barberá, \& Cilla, 2017) \\
\hline Ferric pyrophosphate & Poorly soluble & 92 & $\begin{array}{l}\text { Fruit juice, } \\
\text { bouillon cubes }\end{array}$ & $\begin{array}{l}\text { (Blanco-Rojo et al., 2011b; Navas-Carretero } \\
\text { et al., 2007a; Navas-Carretero et al., 2009; } \\
\text { Navas-Carretero et al., 2007b; Toxqui et al., } \\
\text { 2013) }\end{array}$ \\
\hline \multicolumn{5}{|l|}{ Nanoparticulate iron } \\
\hline Iron oxide & $\begin{array}{l}\text { Coating } \\
\text { dependent }\end{array}$ & - & - & (Chamorro et al., 2015) \\
\hline Iron oxyhydroxides & $\begin{array}{l}\text { Coating } \\
\text { dependent }\end{array}$ & - & & (Pereira et al., 2014) \\
\hline Ferritin mimetic iron & $\begin{array}{l}\text { Coating } \\
\text { dependent }\end{array}$ & & - & $\begin{array}{l}\text { (Aslam et al., 2014; Latunde-Dada et al., } \\
\text { 2014) }\end{array}$ \\
\hline
\end{tabular}

* To ferrous sulfate, 7 $\mathrm{H}_{2} \mathrm{O}$. Adapted from WHO, 2006; Hurrell, 2010; Diego Quintaes, Barberá, \& Cilla, 2017. 
Highlights:

- Iron is the most challenging micronutrient to add to produce fortified food

- The choices of iron form, food vehicle and target population are decisive

- Other food components and meal composition may greatly modify iron bioavailability

- Safety issues are related to the iron fortified food and also to consumer protection 


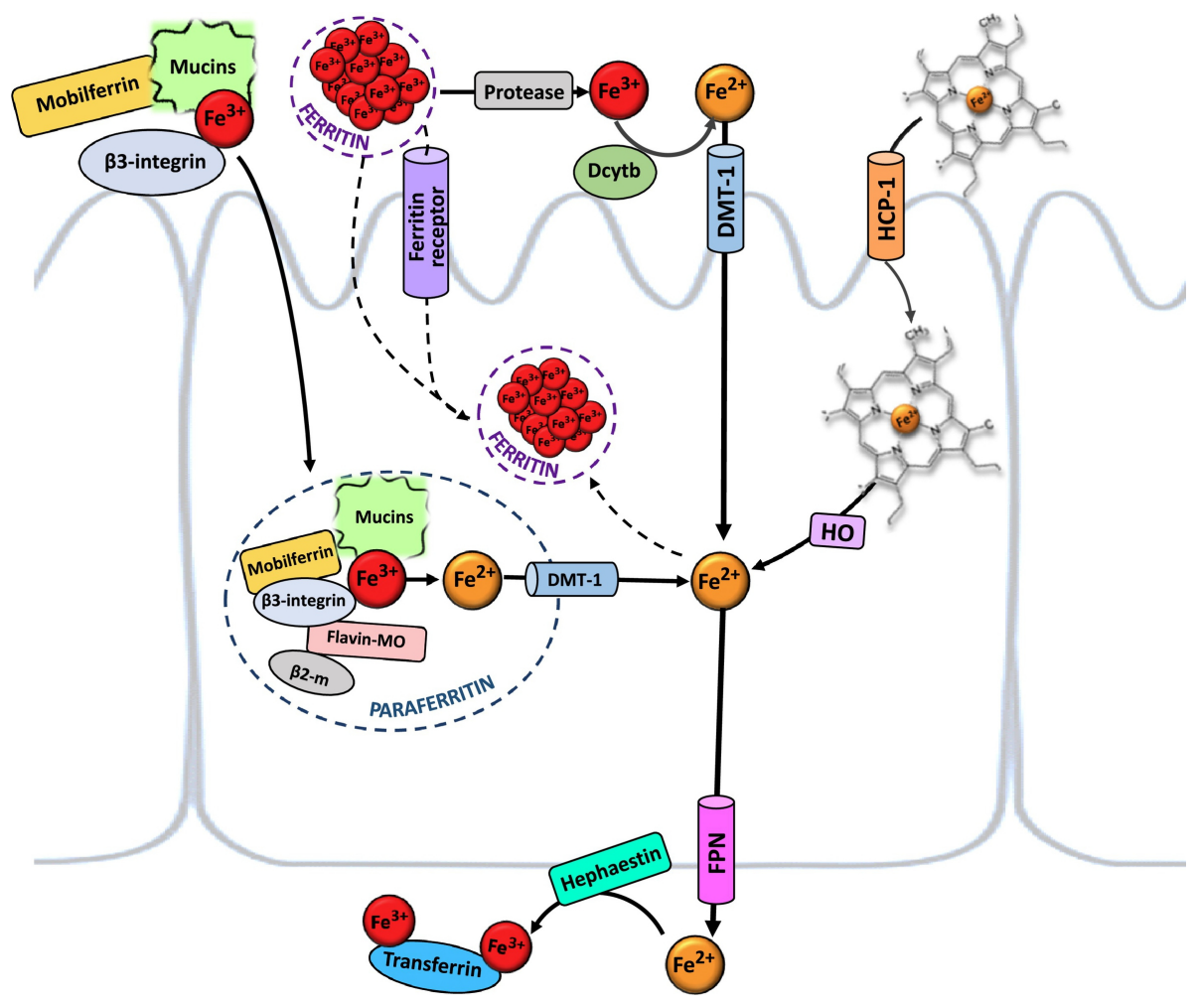

Figure 1 


\section{Iron bioavailability}

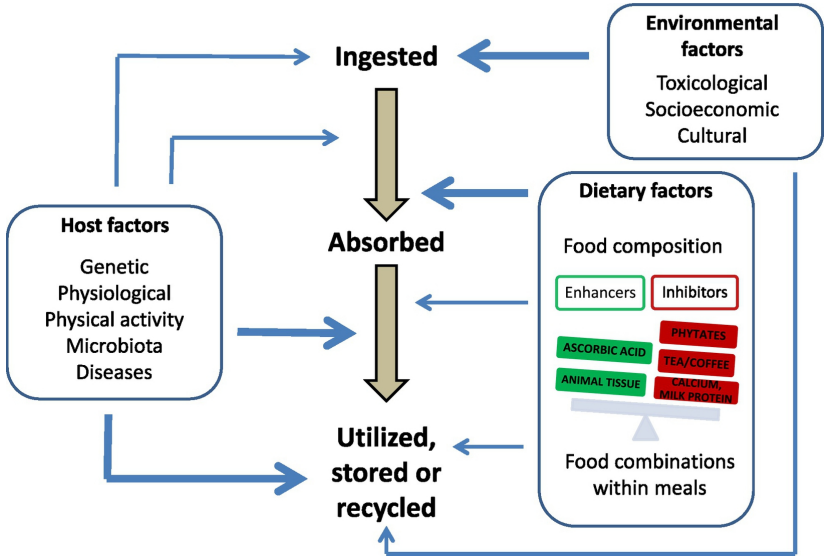

Figure 2 


\section{Strategies to improve iron bioavailability of fortified food}

\begin{tabular}{l} 
Iron fortificant \\
Iron compound and coating: \\
- $\quad$ Iron salt, elemental iron \\
- $\quad$ Microencapsulation \\
Reduction of the iron \\
particle size: \\
- $\quad$ Micronized iron \\
- $\quad$ Nanosized iron \\
\hline
\end{tabular}

\begin{tabular}{|l|}
\hline \multicolumn{1}{|c|}{ Food matrix } \\
Contains iron absorption \\
enhancers: \\
- Ascorbic acid \\
- $\quad$ Animal tissue \\
Does not contain iron \\
absorption inhibitors: \\
- $\quad$ Phytates \\
- Polyphenols \\
- $\quad$ Calcium \\
- $\quad$ Casein \\
- $\quad$ Other divalent metals \\
\hline
\end{tabular}

\section{Target population}

Iron deficiency population:

- Pregnant women

- Women at childbearing age

- Infants and children

- Athletes

- Elderly 